\title{
Ligand-Interchange Reactions Between M(IV) (M = Ti, V) Oxide Bis- Acetylacetonates and Halides of High Valent Groups 4 and 5 Metals. A Synthetic and Electrochemical Study
}

\author{
Tiziana Funaioli, ${ }^{a}$ Fabio Marchetti, ${ }^{*}, a$ Guido Pampaloni, ${ }^{a}$ Stefano Zacchini ${ }^{b}$ \\ ${ }^{a}$ University of Pisa, Dipartimento di Chimica e Chimica Industriale, Via Risorgimento 35, I-56126 Pisa, Italy. Tel: +39 \\ 050 2219245; E-mail: fabmar@dcci.unipi.it.Webpage: http://www.dcci.unipi.it/ fabmar/ \\ ${ }^{b}$ University of Bologna, Dipartimento di Chimica Industriale "Toso Montanari", Viale Risorgimento 4, I-40136 \\ Bologna, Italy.
} This submission was created using the RSC Article Template (DO NOT DELETE THIS TEXT)
(LINE INCLUDED FOR SPACING ONLY - DO NOT DELETE THIS TEXT)

\begin{abstract}
The reactions of $\mathrm{M}^{\prime} \mathrm{O}(\mathrm{acac})_{2}\left[\mathrm{M}^{\prime}=\mathrm{Ti}, \mathrm{V}\right.$; acac $=$ acetylacetonato anion] with equimolar amounts of $\mathrm{MF}_{5}(\mathrm{M}=\mathrm{Nb}, \mathrm{Ta})$ in $\mathrm{CH}_{2} \mathrm{Cl}_{2}$ afforded $\mathrm{Ti}(\mathrm{acac})_{2} \mathrm{~F}_{2}, \mathbf{1 a}$, and $\left[\mathrm{V}(\mathrm{acac})_{3}\right]\left[\mathrm{MF}_{6}\right](\mathrm{M}=\mathrm{Nb}, \mathbf{4 a} ; \mathrm{M}=\mathrm{Ta}, \mathbf{4 b})$, respectively. $\mathrm{MOF}_{3}(\mathrm{M}=\mathrm{Nb}, \mathbf{2 a} ; \mathrm{M}=\mathrm{Ta}$, 2b) were co-produced from $\mathrm{MF}_{5} / \mathrm{TiO}(\mathrm{acac})_{2}$. The intermediate species $\left[\mathrm{TaF}_{4}\left\{\mathrm{OTi}(\mathrm{acac})_{2}\right\}_{2}\right]\left[\mathrm{TaF}_{6}\right], \mathbf{3}$, was intercepted in the course of the formation of $\mathbf{1 a}$ from $\mathrm{TiO}(\mathrm{acac})_{2} / \mathrm{TaF}_{5} . \mathrm{NbCl}_{5}$ reacted with $\mathrm{TiO}(\mathrm{acac})_{2}$ yielding selectively the previously reported $\left[\mathrm{NbO}(\mathrm{acac}) \mathrm{Cl}_{2}\right]_{\mathrm{x}}, \mathbf{5}$, and $\mathrm{Ti}_{2}(\mathrm{acac})_{2}(\mu-\mathrm{Cl})_{2} \mathrm{Cl}_{4}, \mathbf{6}$. Complex 6 was alternatively obtained from the addition of a two-fold excess of $\mathrm{TiCl}_{4}$ to $\mathrm{VO}(\mathrm{acac})_{2}$. The $1: 1 \mathrm{reactions}$ of TiX $4(\mathrm{X}=\mathrm{F}, \mathrm{Cl})$ with $\mathrm{TiO}(\mathrm{acac})_{2}$ in dichloromethane gave $\mathrm{Ti}(\mathrm{acac})_{2} \mathrm{X}_{2}(\mathrm{X}=\mathrm{F}, \mathbf{1 a} ; \mathrm{X}=\mathrm{Cl}, \mathbf{1 b})$ and $\mathrm{TiOX}_{2}(\mathrm{X}=\mathrm{F}, \mathbf{7 a} ; \mathrm{X}=\mathrm{Cl}, 7 \mathbf{b})$. The $1: 1$ combination of $\mathrm{TiX}_{4}(\mathrm{X}=\mathrm{F}, \mathrm{Cl})$ with $\mathrm{VO}(\mathrm{acac})_{2}$ led to $\mathbf{1} \mathbf{a}, \mathbf{b}$ and $\operatorname{VOX}_{2}(\mathrm{X}=\mathrm{F}, \mathbf{8} \mathbf{a} ; \mathrm{X}=\mathrm{Cl}, \mathbf{8 b})$. The $\mu$-oxido compounds $\left(\mathrm{C}_{6} \mathrm{~F}_{5}\right)_{3} \mathrm{~B}-\mathrm{O}-\mathrm{M}^{\prime}(\mathrm{acac})_{2}\left(\mathrm{M}^{\prime}=\mathrm{Ti}, \mathrm{V}\right)$ underwent fragmentation by $\left[\mathrm{PF}_{6}\right]^{-}$in chlorinated solvent, yielding $\mathrm{POF}_{3}, \mathbf{9}$, and $\left[\mathrm{B}\left(\mathrm{C}_{6} \mathrm{~F}_{5}\right)_{3} \mathrm{~F}\right]^{-}, \mathbf{1 0}$, according to NMR studies; 1a and $\mathrm{V}(\mathrm{acac})_{3}{ }^{+}$, respectively, were detected as the metal-containing species. Electrochemical studies were carried out aimed at the full characterization of the products and the observation of possible degradation pathways.
\end{abstract}

\section{Introduction}

In principle, the direct combination of a metal-containing Lewisbase fragment of the type [M-O] with an oxophilic metal species (Lewis acid, $\mathrm{M}^{\prime}$ ) affords a $\left[\mathrm{M}-\mathrm{O}-\mathrm{M}^{\prime}\right]$ adduct. This strategy has been employed for the preparation of O-bridged $\left[\mathrm{M}-\mathrm{O}-\mathrm{M}^{\prime}\right]$ derivatives, ${ }^{1}$ comprising either two transition metal centres ${ }^{2}$ or a transition metal adjacent to a main group element such as boron ${ }^{3}$ and phosphorous. ${ }^{4}\left[\mathrm{M}-\mathrm{O}-\mathrm{M}^{\prime}\right]$ compounds are potential intermediates in oxygen atom transfer reactions, ${ }^{5}$ including the synthesis of diverse metal derivatives employed in homogeneous catalysis. ${ }^{6}$

Recently, we have been involved in the study of the reactivity of niobium and tantalum pentahalides, $\mathrm{MX}_{5}(\mathrm{M}=\mathrm{Nb}, \mathrm{Ta} ; \mathrm{X}=\mathrm{F}$, $\mathrm{Cl}, \mathrm{Br}, \mathrm{I}),{ }^{7,8}$ with potential oxygen donor ligands. ${ }^{9}$ According to our findings, the high reactivity of $\mathrm{MX}_{5}$ towards $O$-containing species frequently renders the $O$-to-metal coordination just the preliminary step of subsequent fragmentation of the oxygen substrate. Thus, oxygen abstraction by the metal centre has been observed in a number of cases, resulting in formation of the oxidohalide unit $\left[\mathrm{MOX}_{3}\right](\mathrm{X}=\mathrm{Cl}, \mathrm{Br}) .{ }^{10}$ Interestingly, when the $O$ abstraction reaction is carried out with opportune stoichiometry, stable oxido-bridged dinuclear adducts of formula $\mathrm{X}_{5} \mathrm{M}-\mathrm{O}$ $\mathrm{MX}_{3}(O-O)\left[\mathrm{M}=\mathrm{Nb}, \mathrm{Ta} ; \mathrm{X}=\mathrm{Cl}, \mathrm{Br} ; O-O=\mathrm{MeO}\left(\mathrm{CH}_{2}\right)_{2} \mathrm{OMe}\right.$, $\left.\mathrm{MeOCH}_{2} \mathrm{CO}_{2} \mathrm{Me},\left(\mathrm{MeCO}_{2}\right) \mathrm{CH}=\mathrm{CH}\left(\mathrm{CO}_{2} \mathrm{Me}\right), \mathrm{CH}_{2}\left(\mathrm{CO}_{2} \mathrm{Me}\right)_{2}\right]$ are obtained. Spectroscopic and $\mathrm{X}$-ray evidence suggest that the latter dinuclear compounds could be viewed as coordination adducts of the inorganic oxygen ligand $\mathrm{O}=\mathrm{MX}_{3}(O-O)$ with $\mathrm{MX}_{5}$.

In the light of this preface, we became interested in the reactivity of $\mathrm{MX}_{5}$ with coordination complexes containing a metaloxygen moiety. Our choice fell on $\mathrm{M}^{\prime} \mathrm{O}(\mathrm{acac})_{2}\left(\mathrm{M}^{\prime}=\mathrm{Ti}^{11},{ }^{12} \mathrm{~V}\right.$; acac $=$ acetylacetonato $)$, on account of their easy availability and their proved capability to bind Lewis acidic species. ${ }^{13}$ As a natural extension, the group 4 tetrahalides $\mathrm{TiX}_{4}(\mathrm{X}=\mathrm{F}, \mathrm{Cl})$ were included in the investigation. ${ }^{14}$

We show herein that the reactions of $\mathrm{M}^{\prime} \mathrm{O}(\mathrm{acac})_{2}$ with high-valent metal halides occur with highly selective interchange of ligands between the different metal centres. Evidence will be provided for the establishment of metal-O- $\mathrm{M}^{\prime}$ interaction in the course of those reactions proceeding with oxygen transfer. The electrochemistry section will describe the electrochemical behaviour of the previously reported compounds $\mathrm{M}^{\prime} \mathrm{O}(\mathrm{acac})_{2}\left(\mathrm{M}^{\prime}=\mathrm{Ti}, \mathrm{V}\right),\left(\mathrm{C}_{6} \mathrm{~F}_{5}\right)_{3} \mathrm{~B}-\mathrm{O}-\mathrm{M}^{\prime}(\mathrm{acac})_{2}$ and $\mathbf{1 a}, \mathbf{b}$, and of the new ones $\mathbf{3}$ and $\mathbf{4 a , b}$. Our outcomes supply novel, possible procedures for the synthesis of mixed-ligand early transition metal derivatives.

\section{Results and Discussion}

\section{Synthesis and Characterization}

The group 5 metal pentafluorides $\mathrm{MF}_{5}(\mathrm{M}=\mathrm{Nb}, \mathrm{Ta})$ reacted with $\mathrm{TiO}(\mathrm{acac})_{2}$ in chlorinated solvent affording $\mathrm{Ti}(\mathrm{acac})_{2} \mathrm{~F}_{2}, \mathbf{1 a}$, and $\mathrm{MOF}_{3}(\mathrm{M}=\mathrm{Nb}, \mathbf{2} \mathbf{a} ; \mathrm{M}=\mathrm{Ta}, \mathbf{2 b})$ in good yields, see Equation (1). The previously reported compound $\mathbf{1} \mathbf{a}^{15}$ has been identified by elemental analysis and NMR spectroscopy (see Experimental for details), and characterized by X-ray diffractometry (Figure 1 and Table 1). ${ }^{16}$ Evidence for the formation of $\mathbf{2 a}$, $\mathbf{b}$ have been collected by IR spectroscopy (band around $1000 \mathrm{~cm}^{-117}$ ) and analysis of the metal content (see Experimental).

$$
\mathrm{MF}_{5}+\mathrm{TiO}(\mathrm{acac})_{2} \rightarrow \underset{\mathbf{1 a}}{\rightarrow \mathrm{Ti}(\mathrm{acac})_{2} \mathrm{~F}_{2}+\mathrm{MOF}_{3}}(\mathrm{M}=\mathrm{Nb}, \mathbf{2 a} ; \mathrm{Ta}, \mathbf{2 b})
$$

It should be noted that the procedures available in the literature for the preparation of $\mathbf{2} \mathbf{a}, \mathbf{b}$ usually require severe conditions. ${ }^{17,18}$ 


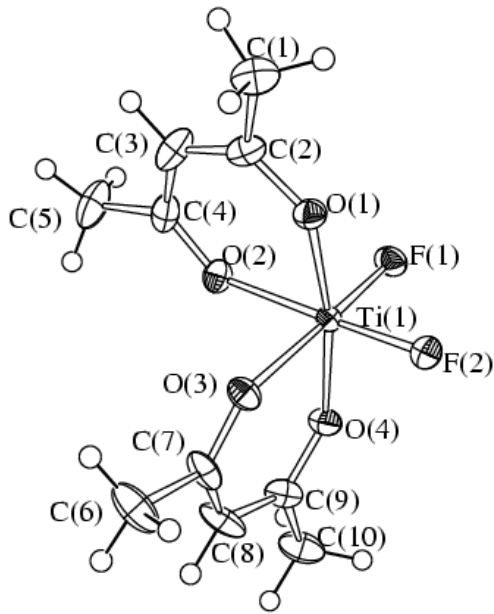

Figure 1. Molecular structure of $\mathrm{Ti}(\mathrm{acac})_{2} \mathrm{~F}_{2} \cdot 0.5 \mathrm{C}_{2} \mathrm{H}_{4} \mathrm{Cl}_{2}, \mathbf{1 a} \cdot 0.5 \mathrm{C}_{2} \mathrm{H}_{4} \mathrm{Cl}_{2}$ (dichloroethane solvate not shown). Displacement ellipsoids are at the $50 \%$ probability level.

Table 1. Selected bond lengths ( $\AA$ ) and angles $\left({ }^{\circ}\right)$ for Ti(acac) $)_{2} \mathrm{~F}_{2} \cdot 0.5 \mathrm{C}_{2} \mathrm{H}_{4} \mathrm{Cl}_{2}\left(\mathbf{1 a} \cdot 0.5 \mathrm{C}_{2} \mathrm{H}_{4} \mathrm{Cl}_{2}\right)$.

\begin{tabular}{llll}
\hline $\mathrm{F}(1)-\mathrm{Ti}(1)$ & $1.799(4)$ & $\mathrm{F}(2)-\mathrm{Ti}(1)$ & $1.806(4)$ \\
$\mathrm{O}(1)-\mathrm{Ti}(1)$ & $1.954(5)$ & $\mathrm{O}(2)-\mathrm{Ti}(1)$ & $2.006(5)$ \\
$\mathrm{O}(3)-\mathrm{Ti}(1)$ & $2.004(5)$ & $\mathrm{O}(4)-\mathrm{Ti}(1)$ & $1.938(5)$ \\
$\mathrm{C}(1)-\mathrm{C}(2)$ & $1.503(10)$ & $\mathrm{C}(2)-\mathrm{O}(1)$ & $1.295(8)$ \\
$\mathrm{C}(2)-\mathrm{C}(3)$ & $1.389(11)$ & $\mathrm{C}(3)-\mathrm{C}(4)$ & $1.387(11)$ \\
$\mathrm{C}(4)-\mathrm{O}(2)$ & $1.260(9)$ & $\mathrm{C}(4)-\mathrm{C}(5)$ & $1.498(10)$ \\
$\mathrm{C}(6)-\mathrm{C}(7)$ & $1.501(10)$ & $\mathrm{C}(7)-\mathrm{O}(3)$ & $1.272(8)$ \\
$\mathrm{C}(7)-\mathrm{C}(8)$ & $1.405(11)$ & $\mathrm{C}(8)-\mathrm{C}(9)$ & $1.390(10)$ \\
$\mathrm{C}(9)-\mathrm{O}(4)$ & $1.271(8)$ & $\mathrm{C}(9)-\mathrm{C}(10)$ & $1.487(10)$ \\
& & & \\
$\mathrm{C}(2)-\mathrm{O}(1)-\mathrm{Ti}(1)$ & $134.2(5)$ & $\mathrm{C}(4)-\mathrm{O}(2)-\mathrm{Ti}(1)$ & $133.2(5)$ \\
$\mathrm{C}(7)-\mathrm{O}(3)-\mathrm{Ti}(1)$ & $132.7(4)$ & $\mathrm{C}(9)-\mathrm{O}(4)-\mathrm{Ti}(1)$ & $135.9(5)$ \\
$\mathrm{F}(1)-\mathrm{Ti}(1)-\mathrm{F}(2)$ & $96.3(2)$ & $\mathrm{F}(1)-\mathrm{Ti}(1)-\mathrm{O}(4)$ & $90.64(19)$ \\
$\mathrm{F}(2)-\mathrm{Ti}(1)-\mathrm{O}(4)$ & $97.9(2)$ & $\mathrm{F}(1)-\mathrm{Ti}(1)-\mathrm{O}(1)$ & $97.1(2)$ \\
$\mathrm{F}(2)-\mathrm{Ti}(1)-\mathrm{O}(1)$ & $88.0(2)$ & $\mathrm{O}(4)-\mathrm{Ti}(1)-\mathrm{O}(1)$ & $169.7(2)$ \\
$\mathrm{F}(1)-\mathrm{Ti}(1)-\mathrm{O}(3)$ & $171.7(2)$ & $\mathrm{F}(2)-\mathrm{Ti}(1)-\mathrm{O}(3)$ & $90.2(2)$ \\
$\mathrm{O}(4)-\mathrm{Ti}(1)-\mathrm{O}(3)$ & $83.4(2)$ & $\mathrm{O}(1)-\mathrm{Ti}(1)-\mathrm{O}(3)$ & $88.2(2)$ \\
$\mathrm{F}(1)-\mathrm{Ti}(1)-\mathrm{O}(2)$ & $89.9(2)$ & $\mathrm{F}(2)-\mathrm{Ti}(1)-\mathrm{O}(2)$ & $170.1(2)$ \\
$\mathrm{O}(4)-\mathrm{Ti}(1)-\mathrm{O}(2)$ & $89.6(2)$ & $\mathrm{O}(1)-\mathrm{Ti}(1)-\mathrm{O}(2)$ & $83.6(2)$ \\
$\mathrm{O}(3)-\mathrm{Ti}(1)-\mathrm{O}(2)$ & $84.2(2)$ & & \\
\hline
\end{tabular}

Complex 1a displays a distorted octahedral geometry with the F-ligands in mutual cis-position, as previously found in $\mathrm{Ti}(\mathrm{acac})_{2} \mathrm{Cl}_{2}{ }^{15 b, 19}$ and in the closely related complexes cis-Ti[ $\kappa^{2}-$ $\left.\mathrm{RC}(\mathrm{O}) \mathrm{CHC}(\mathrm{O}) \mathrm{R}^{\prime}\right]_{2} \mathrm{Cl}_{2}\left(\mathrm{R}=\mathrm{Me}, \mathrm{R}^{\prime}=\mathrm{Ph} ; \mathrm{R}=\mathrm{R}^{\prime}={ }^{\mathrm{t}} \mathrm{Bu}, \mathrm{Ph}\right) .{ }^{20}$

The reaction described in Equation (1) is the result of selective interchange of ligands between different metal centres: the oxygen transfer from $\mathrm{TiO}(\mathrm{acac})_{2}$ to $\mathrm{MF}_{5}$ is counterbalanced by two fluorines following the opposite direction. This fact reflects the increase of the metal-oxygen bond energy on going from Ti $(668$ $\left.\mathrm{kJ} \mathrm{mol}^{-1}\right)$ to $\mathrm{Nb}\left(726.5 \mathrm{~kJ} \mathrm{~mol}^{-1}\right)$ and $\mathrm{Ta}\left(839 \mathrm{~kJ} \mathrm{~mol}^{-1}\right){ }^{21}$

It is reasonable that the interaction between $\mathrm{MF}_{5}$ and $\mathrm{TiO}(\mathrm{acac})_{2}$ begins with the formation of a [M-O-Ti] adduct (see Introduction). Such an adduct could be isolated in good yield in the reaction involving $\mathrm{TaF}_{5}$, and thus identified as $\left[\mathrm{TaF}_{4}\left\{\mathrm{OTi}(\mathrm{acac})_{2}\right\}_{2}\right]\left[\mathrm{TaF}_{6}\right], \mathbf{3}$ (Scheme 1). It is noteworthy that a good number of $\left[\mathrm{TaF}_{4}(\mathrm{~L})_{\mathrm{x}}\right]\left[\mathrm{TaF}_{6}\right]$ complexes $(\mathrm{x}=2-4)$ have been described as obtained by the addition of O- ${ }^{9,22}$ or S-donors ${ }^{23}$ to $\mathrm{TaF}_{5}$. The molar conductivity value of $\mathbf{3}$ (in $\mathrm{CH}_{2} \mathrm{Cl}_{2}$ solution) manifests the ionic nature. ${ }^{9,22 b}$ In addition, the ${ }^{19} \mathrm{~F}$ NMR spectrum clearly shows the resonance due to the $\left[\mathrm{TaF}_{6}\right]^{-}$anion at typical chemical shift $(\delta=38.4 \mathrm{ppm}) ;{ }^{9,22,23}$ instead no ${ }^{19} \mathrm{~F}$ signal has been found for the $\left[\mathrm{TaF}_{4}\right]^{+}$moiety, in analogy with previous findings for similar salts. ${ }^{24}$ The ${ }^{1} \mathrm{H}$ and ${ }^{13} \mathrm{C}$ NMR spectra of 3 (in $\mathrm{CD}_{2} \mathrm{Cl}_{2}$ ) contain the resonances of the bidentate acac moieties shifted to high frequency with respect to those seen in $\mathrm{TiO}(\mathrm{acac})_{2},{ }^{25}$ as result of the TiO-Ta bond formation. The solid state IR spectrum displays one single carbonyl absorption at $1530 \mathrm{~cm}^{-1}$ (Figure S3 within Supplementary Information). Based on a comparison of the IR spectra of $\mathrm{TiO}(\mathrm{acac})_{2}$ and $\mathbf{3}$ (see Figures $\mathrm{S} 3$ and $\mathrm{S} 1$; the Ti-OTi stretching frequency in $\mathrm{TiO}(\mathrm{acac})_{2}$ falls at $817 \mathrm{~cm}^{-126}$ ), it may be concluded that the titanyl moiety has comparable bond order in such compounds. ${ }^{11}$ Further evidence for the formation of $\mathbf{3}$ will be discussed in the Electrochemistry Section. Compound $\mathbf{3}$ belongs to the rare family of titanyl-Lewis acid addition compounds, that includes $\left(\mathrm{C}_{6} \mathrm{~F}_{5}\right)_{3} \mathrm{~B}-\mathrm{O}-\mathrm{Ti}(\mathrm{acac})_{2}{ }^{13}$

Compound 3 is not stable in $\mathrm{CH}_{2} \mathrm{Cl}_{2}$ solution at room temperature, slowly converting into $\mathbf{1 a}$ and $\mathrm{TaOF}_{3}$ (Scheme 1). This fact prevented X-ray quality crystals from being obtained.

$$
\begin{aligned}
& 2 \mathrm{TaF}_{5}+2 \mathrm{TiO}(\mathrm{acac})_{2} \stackrel{\mathrm{CH}_{2} \mathrm{Cl}_{2}}{\longrightarrow}\left[\begin{array}{c}
\mathrm{OTi}(\mathrm{acac})_{2} \\
\mathrm{l} \\
\mathrm{F}_{4} \mathrm{Ta}-\mathrm{OTi}(\mathrm{acac})_{2}
\end{array}\right] \mathrm{TaF}_{6} \\
& 3 \\
& \rightarrow 2 \mathrm{Ti}(\mathrm{acac})_{2} \mathrm{~F}_{2}+2 \mathrm{TaOF}_{3}
\end{aligned}
$$

Our study went on with the reactions of $\mathrm{MF}_{5}$ with $\mathrm{VO}(\mathrm{acac})_{2}$ in dichloromethane, leading to the clean isolation of the complexes $\left[\mathrm{V}(\mathrm{acac})_{3}\right]\left[\mathrm{MF}_{6}\right](\mathrm{M}=\mathrm{Nb}, \mathbf{4 a} ; \mathrm{M}=\mathrm{Ta}, \mathbf{4 b})$ in good yields (Scheme 2). A non soluble material was obtained as co-product, whose identity could not be ascertained (see Experimental).

$$
\underset{\mathrm{M}=\mathrm{Nb}, \mathrm{Ta}}{\mathrm{MF}_{5}} \stackrel{\mathrm{VO}(\mathrm{acac})_{2}}{\stackrel{\mathrm{CH}_{2} \mathrm{Cl}_{2}, \text { r.t., } 12 \mathrm{~h}}{\longrightarrow} \begin{array}{l}
{\left[\mathrm{V}(\mathrm{acac})_{3}\right]\left[\mathrm{MF}_{6}\right]} \\
\mathrm{M}=\mathrm{Nb}, \mathbf{4 a}, \mathrm{Ta}, \mathbf{4 b}
\end{array}}
$$

Scheme 2. The reactions of $\mathrm{MF}_{5}$ with $\mathrm{VO}(\mathrm{acac})_{2}$.

Although the hexacoordinated $\left[\mathrm{V}(\mathrm{acac})_{3}\right]^{+}$cation ${ }^{27}$ and the $\left[\mathrm{MF}_{6}\right]^{-}$anions ${ }^{9,22 \mathrm{~b}}$ are known species, the ionic derivatives $\mathbf{4 a , b}$ are new compounds that have been characterized by various techniques (see Experimental). Salient feature of the solid state IR spectra (Figures S4 and S5) is the disappearance of the absorption due to the $[\mathrm{V}=\mathrm{O}]$ moiety as found in the parent compound $\mathrm{VO}(\mathrm{acac})_{2}\left(v=992 \mathrm{~cm}^{-1}\right.$, see Figure S2). The absorption related to the carbonyl moieties has been recognized around $1520 \mathrm{~cm}^{-1}$. The ${ }^{1} \mathrm{H}$ and ${ }^{13} \mathrm{C}$ NMR spectra of $\mathbf{4 a}$, b (in $\mathrm{CDCl}_{3}$ ) exhibit one single set of resonances due to the equivalent acac ligands; otherwise the ${ }^{19} \mathrm{~F}$ NMR spectra clearly show the typical resonances related to the $\mathrm{MF}_{6}^{-}$anions. 4a,b are well-soluble in chlorinated solvents, conferring intense violet colour to their solutions, and can be easily isolated in the solid state as microcrystalline materials. X-ray analysis was carried out on $\mathbf{4 b}$, confirming the identity of the compound, ${ }^{28}$ however severe twinning prevented accurate determination of geometric parameters.

The 1:1 molar reaction of $\mathrm{NbCl}_{5}$ with $\mathrm{TiO}(\mathrm{acac})_{2}$ occurs with selective transfer of oxygen ligands from $\mathrm{Ti}$ to $\mathrm{Nb}$, accompanied by reverse $\mathrm{Cl}$ migration. Hence the compounds $\left[\mathrm{NbO}(\text { acac }) \mathrm{Cl}_{2}\right]_{\mathrm{x}}, \mathbf{5},{ }^{29}$ and $\mathrm{Ti}_{2}(\mathrm{acac})_{2}(\mu-\mathrm{Cl})_{2} \mathrm{Cl}_{4}, \mathbf{6}$, which were prepared in the past by different procedures, have been recognized as the major products of the reaction (Scheme 3). The niobium(V) compound $\mathbf{5}$ was clearly identified by elemental analysis and by the IR (solid state) absorptions at 1545 and $815 \mathrm{~cm}^{-1}$, due respectively to the $\mathrm{C}=\mathrm{O}$ and the $\mathrm{Nb}-\mathrm{O}$ stretching vibrations. ${ }^{29}$ The titanium(IV) derivative 6 was crystallized from pentane $/ \mathrm{CH}_{2} \mathrm{Cl}_{2}$ at low temperature and identified by ${ }^{1} \mathrm{H}$ NMR (resonances at 6.00 and $2.19 \mathrm{ppm}$ ), IR (intense band at $1554 \mathrm{~cm}^{-1}$ ) and by comparison of the collected $\mathrm{X}$ ray data with those deposited with the Cambridge Crystallographic Data Centre (Refcode CLACIT). ${ }^{30}$ 


$$
\begin{array}{rl}
\mathrm{NbCl}_{5}+\mathrm{TiO}(\mathrm{acac})_{2} & \underset{\mathrm{C} \mathrm{CH}_{2} \mathrm{Cl}_{2}}{\mathrm{r.t.}, 2 \mathrm{~h}} \\
\mathrm{NbO}(\mathrm{acac}) \mathrm{Cl}_{2} & +0.5 \mathrm{Ti}_{2}(\mathrm{acac})_{2}\left(\mu-\mathrm{Cl}_{2}\right)_{2} \mathrm{Cl}_{4} \\
\mathbf{5} & \mathbf{6}
\end{array}
$$

Scheme 3. Titanium to niobium oxygen ligands transfer.

The study of the reactivity of $\mathrm{M}^{\prime} \mathrm{O}(\mathrm{acac})_{2}\left(\mathrm{M}^{\prime}=\mathrm{Ti}, \mathrm{V}\right)$ with metal halides was extended to titanium tetrahalides. Thus the 1:1 molar reactions of $\mathrm{TiO}(\mathrm{acac})_{2}$ with $\mathrm{TiX}_{4}(\mathrm{X}=\mathrm{F}, \mathrm{Cl})$ gave $\mathrm{Ti}(\mathrm{acac}) \mathrm{X}_{2}\left(\mathrm{X}=\mathrm{F}, \mathbf{1 a} ; \mathrm{X}=\mathrm{Cl}, \mathbf{1} \mathbf{\mathbf { b }}{ }^{15,31}\right)$ and $\mathrm{TiOX}_{2}\left(\mathrm{X}=\mathrm{F}, \mathbf{7} \mathbf{a}{ }^{32}\right.$ $\left.\mathrm{X}=\mathrm{Cl}, 7 \mathbf{b}^{33}\right)$ in high yields, see Equation 2.1 and 7 could be efficiently separated from each other, in the respective cases, by exploiting their different solubilities in the reaction medium. Compound 1b was crystallized from pentane $/ \mathrm{CH}_{2} \mathrm{Cl}_{2}$ at low temperature and characterized by elemental analysis, ${ }^{1} \mathrm{H}-\mathrm{NMR}$ spectroscopy $\left(\mathrm{CDCl}_{3}\right.$ solution; resonances at $\left.6.01,2.17 \mathrm{ppm}\right)$ and by comparison of the obtained X-ray data with those deposited with the Cambridge Crystallographic Data Centre (Refcodes QIHXEX, ZZZEBO). ${ }^{30}$

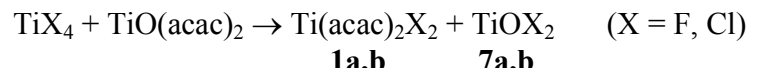

We moved to examine the 1:1 reaction of $\mathrm{VO}(\mathrm{acac})_{2}$ with $\mathrm{TiX}_{4}$ $(\mathrm{X}=\mathrm{F}, \mathrm{Cl})$. The formation of the hypothetical vanadium derivatives $\mathrm{V}(\mathrm{acac})_{2} \mathrm{X}_{2}\left(\mathrm{X}=\mathrm{F}, \mathrm{Cl}^{34}\right.$ ) was not observed (Scheme 4 , pathway a). Instead 1a,b were selectively obtained and identified (Scheme 4, pathway b); in addition, the oxido-halides $\operatorname{VOX}_{2}(\mathrm{X}=$ $\mathrm{F}, \mathbf{8} \mathbf{a} ;{ }^{35} \mathrm{X}=\mathrm{Cl}, \mathbf{8 b}{ }^{36}$ ) were recognized as co-products in the respective cases. These outcomes indicate that selective interchange of $\mathrm{X}$ and acac ligands (Scheme 4, pathway b) rather than oxygen transfer (Scheme 4, pathway a) takes place between the metal centres. The same mechanism might be operative in the reactions indicated in Equation 2.

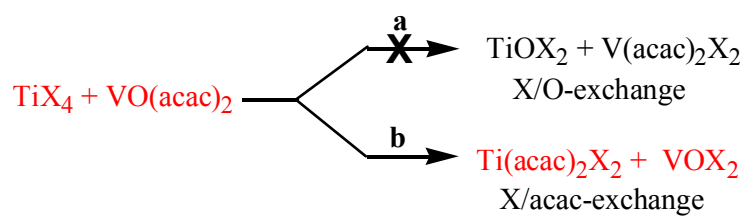

Scheme 4. Reactions of $\mathrm{TiX}_{4}$ with $\mathrm{VO}(\mathrm{acac})_{2}$.

When the reaction of $\mathrm{TiCl}_{4}$ with $\mathrm{VO}(\mathrm{acac})_{2}$ was performed by using a Ti/ $/ \mathrm{V}>2$ molar ratio, the crystalline, dinuclear compound $6^{50}$ was recovered in good yield in the place of $\mathrm{Ti}(\mathrm{acac})_{2} \mathrm{Cl}_{2}$ [Equation (3)]. $\mathrm{VOCl}_{2}$ was found to be the reaction co-product.

$$
2 \mathrm{TiCl}_{4}+\mathrm{VO}(\mathrm{acac})_{2} \rightarrow \mathrm{Ti}_{2}(\mathrm{acac})_{2}(\mu-\mathrm{Cl})_{2} \mathrm{Cl}_{4}+\mathrm{VOCl}_{2}
$$

\section{Electrochemistry}

To the best of our knowledge, no cyclic voltammetric study has been performed on $\mathrm{TiO}(\mathrm{acac})_{2}$ heretofore, while the literature data related to $\mathrm{VO}(\mathrm{acac})_{2}$ are rather sparse. ${ }^{37}$ Therefore we decided to start our investigation with the study of the $\mathrm{CV}$ behaviour of $\mathrm{M} \mathrm{O}(\mathrm{acac})_{2}$ $\left(\mathrm{M}^{\prime}=\mathrm{Ti}, \mathrm{V}\right)$.

We found that $\mathrm{TiO}(\mathrm{acac})_{2}$ underwent a reduction process at -1.79 $\mathrm{V}$ in $\mathrm{CH}_{2} \mathrm{Cl}_{2}$ solution in the presence of $\left[\mathrm{N}^{n} \mathrm{Bu}_{4}\right]\left[\mathrm{PF}_{6}\right]$ as supporting electrolyte (Table 2) ${ }^{38}$ Instead the vanadium(IV) analogue underwent a reversible one-electron oxidation at $+0.66 \mathrm{~V}$, and one irreversible reduction at $-2.32 \mathrm{~V}\left(v s . \mathrm{FeCp}_{2}\right)^{39}$ (Table 2). Analysis of the cyclic voltammetric response with scan rates varying between 0.02 and 1.00 $\mathrm{V} \mathrm{s}^{-1}$ has confirmed the electrochemically-reversible nature of the reduction of $\mathrm{TiO}(\mathrm{acac})_{2}$ (the peak-to-peak separation $\Delta E_{p}$ approaches the theoretical value of $59 \mathrm{mV}^{40}$ ). This reduction is complicated by a

\begin{tabular}{|c|c|c|c|c|c|c|}
\hline & $E^{\text {ol }}$ & $\Delta E_{p}$ & $E^{\text {ol }}$ & $\Delta E_{p}{ }^{\mathrm{b}}$ & $E^{\circ 1}$ & $\Delta E_{p}{ }^{\mathrm{b}}$ \\
\hline & \multicolumn{3}{|c|}{ Oxidation } & \multicolumn{3}{|c|}{ Reduction } \\
\hline $\mathrm{TiO}(\mathrm{acac})_{2}$ & & & $-1.79^{\mathrm{c}}$ & 66 & & \\
\hline $\mathrm{VO}(\mathrm{acac})_{2}$ & +0.66 & 70 & $-2.32^{\mathrm{d}}$ & & & \\
\hline$\left(\mathrm{C}_{6} \mathrm{~F}_{5}\right)_{3} \mathrm{~B}-\mathrm{O}-\mathrm{V}(\mathrm{acac})_{2}{ }^{\mathrm{e}}$ & & & $-0.90^{\mathrm{c}}$ & 90 & $-2.36^{\mathrm{d}}$ & \\
\hline$\left(\mathrm{C}_{6} \mathrm{~F}_{5}\right)_{3} \mathrm{~B}-\mathrm{O}-\mathrm{Ti}(\mathrm{acac})_{2}$ & & & $-0.56^{\mathrm{c}}$ & 70 & $-2.40^{\mathrm{d}}$ & \\
\hline$\left[\mathrm{V}(\mathrm{acac})_{3}\right]^{+}$ & & & +0.24 & 65 & -2.02 & 90 \\
\hline$\left[\mathrm{TaF}_{4}\left\{\mathrm{OTi}(\mathrm{acac})_{2}\right\}_{2}\right]^{+}$ & & & $-0.57^{\mathrm{c}}$ & 62 & $-2.37^{\mathrm{d}}$ & \\
\hline $1 \mathrm{a}$ & & & $-1.29^{\mathrm{c}}$ & 92 & & \\
\hline $1 b^{f}$ & & & $-0.69^{\mathrm{c}}$ & 70 & & \\
\hline
\end{tabular}

subsequent chemical reaction $\left(i_{\mathrm{pa}} / i_{\mathrm{pc}}=0.8\right.$ at $\left.0.10 \mathrm{~V} \mathrm{~s}^{-1}\right)$.

Table 2. Formal electrode potentials $\left(\mathrm{V}, v s . \mathrm{FeCp}_{2}{ }^{\mathrm{a}}\right)$ and peak-to-peak separations $(\mathrm{mV})$ in $0.2 \mathrm{M}\left[\mathrm{N}^{n} \mathrm{Bu}_{4}\right]\left[\mathrm{PF}_{6}\right] / \mathrm{CH}_{2} \mathrm{Cl}_{2}$ solution for the cited redox changes.

${ }^{a}$ Under the cited experimental conditions, the redox process relative to the ferrocene/ferrocenium couple was observed at $+0.39 \mathrm{~V} v s$. SCE. ${ }^{\mathrm{b}}$ Measured at $0.1 \mathrm{~V} \mathrm{~s}^{-1} .{ }^{\mathrm{c}}$ Partially chemically-reversible process. ${ }^{\mathrm{d}}$ Peak potential value for irreversible processes. ${ }^{\mathrm{e}}$ In $\left[\mathrm{N}^{n} \mathrm{Bu}_{4}\right]\left[\mathrm{BPh}_{4}\right] / \mathrm{CH}_{2} \mathrm{Cl}_{2}$ solution. ${ }^{\mathrm{f}}$ In $\left[\mathrm{N}^{n} \mathrm{Bu}_{4}\right]\left[\mathrm{ClO}_{4}\right] / \mathrm{CH}_{2} \mathrm{Cl}_{2}$ solution.

In view of the hypothetical bonding similarities between the stable [B-O-M'] compounds $\left(\mathrm{C}_{6} \mathrm{~F}_{5}\right)_{3} \mathrm{~B}-\mathrm{O}-\mathrm{M}^{\prime}(\mathrm{acac})_{2}\left(\mathrm{M}^{\prime}=\mathrm{Ti}, \mathrm{V}\right){ }^{13}$ and the possible intermediates formed in the reactions between $\mathrm{M}^{\prime} \mathrm{O}(\mathrm{acac})_{2}$ and metal halides, we decided to examine the electrochemical behaviour of $\left(\mathrm{C}_{6} \mathrm{~F}_{5}\right)_{3} \mathrm{~B}-\mathrm{O}-\mathrm{M}^{\prime}(\mathrm{acac})_{2}$.

Green crystals of $\left(\mathrm{C}_{6} \mathrm{~F}_{5}\right)_{3} \mathrm{~B}-\mathrm{O}-\mathrm{V}(\mathrm{acac})_{2}$ dissolved into a $\mathrm{CH}_{2} \mathrm{Cl}_{2}$ solution of $\left[\mathrm{N}^{n} \mathrm{Bu}_{4}\right]\left[\mathrm{PF}_{6}\right]$ (supporting electrolyte) giving a deep-violet solution. This latter exhibited a voltammetric profile with two reversible monoelectronic reductions at +0.24 and $-2.02 \mathrm{~V}$. Otherwise, the yellow titanium species $\left(\mathrm{C}_{6} \mathrm{~F}_{5}\right)_{3} \mathrm{~B}-\mathrm{O}-\mathrm{Ti}(\mathrm{acac})_{2}$ dissolved into $\mathrm{CH}_{2} \mathrm{Cl}_{2} /\left[\mathrm{N}^{n} \mathrm{Bu}_{4}\right]\left[\mathrm{PF}_{6}\right]$ to give a yellow solution. The voltammetric profile of this latter solution did change in some minutes: the initial reversible reduction at $-0.56 \mathrm{~V}\left(i_{\mathrm{pa}} / i_{\mathrm{pc}}=0.94\right.$ at $\left.0.10 \mathrm{~V} \mathrm{~s}^{-1}\right)$ and the irreversible one at $-2.40 \mathrm{~V}$ progressively disappeared, while a new reduction wave at $-1.29 \mathrm{~V}$ became evident.

These outcomes indicate that the electrolyte $\left[\mathrm{N}^{n} \mathrm{Bu}_{4}\right]\left[\mathrm{PF}_{6}\right]$ is not inert towards $\left(\mathrm{C}_{6} \mathrm{~F}_{5}\right)_{3} \mathrm{~B}-\mathrm{O}-\mathrm{M}^{\prime}(\mathrm{acac})_{2}$; therefore, we considered $\left[\mathrm{N}^{n} \mathrm{Bu}_{4}\right]\left[\mathrm{BPh}_{4}\right]$ as alternative electrolyte. Hence green $\left(\mathrm{C}_{6} \mathrm{~F}_{5}\right)_{3} \mathrm{~B}-\mathrm{O}$ $\mathrm{V}(\mathrm{acac})_{2}$ dissolved into $\mathrm{CH}_{2} \mathrm{Cl}_{2} /\left[\mathrm{N}^{n} \mathrm{Bu}_{4}\right]\left[\mathrm{BPh}_{4}\right]$ to give a light-green solution. Subsequent cyclic voltammetry showed one reversible reduction process at $-0.90 \mathrm{~V}$ (complicated by a subsequent chemical reaction, $i_{\mathrm{pa}} / i_{\mathrm{pc}}=0.8$ at $\left.0.10 \mathrm{~V} \mathrm{~s}^{-1}\right)$, followed by an irreversible reduction at $-2.36 \mathrm{~V}$. These reductions were no longer appreciable after some minutes. The light-yellow solution of $\left(\mathrm{C}_{6} \mathrm{~F}_{5}\right)_{3} \mathrm{~B}-\mathrm{O}$ $\mathrm{Ti}(\mathrm{acac})_{2}$ in $\left[\mathrm{N}^{n} \mathrm{Bu}_{4}\right]\left[\mathrm{BPh}_{4}\right] / \mathrm{CH}_{2} \mathrm{Cl}_{2}$ showed only irreversible reduction processes at potentials lower than $-1.5 \mathrm{~V}$. Based on all of these evidences, we have assigned the reductions at $-0.90 \mathrm{~V}$ and at $-0.56 \mathrm{~V}$ to $\left(\mathrm{C}_{6} \mathrm{~F}_{5}\right)_{3} \mathrm{~B}-\mathrm{O}-\mathrm{V}(\mathrm{acac})_{2}$ and $\left(\mathrm{C}_{6} \mathrm{~F}_{5}\right)_{3} \mathrm{~B}-\mathrm{O}-\mathrm{Ti}(\mathrm{acac})_{2}$, respectively (Table 2).

We are able to conclude that the coordination to the strongly electron-deficient $\mathrm{B}\left(\mathrm{C}_{6} \mathrm{~F}_{5}\right)_{3}$ enhances the tendency of $\mathrm{M}^{\prime} \mathrm{O}(\mathrm{acac})_{2}(\mathrm{M}=$ $\mathrm{Ti}, \mathrm{V})$ to be reduced. Furthermore, the so formed $\left[\left(\mathrm{C}_{6} \mathrm{~F}_{5}\right)_{3} \mathrm{~B}-\mathrm{O}-\mathrm{M}^{\prime}(\mathrm{acac})_{2}\right]$ frames are susceptible to reaction with $\left[\mathrm{PF}_{6}\right]^{-}$ (Scheme 5). Thus NMR experiments were carried out in order to shed light on this point. According to the NMR outcomes, $\mathrm{O} / \mathrm{F}$ interchange takes place between $\left[\left(\mathrm{C}_{6} \mathrm{~F}_{5}\right)_{3} \mathrm{~B}-\mathrm{O}-\mathrm{M}^{\prime}(\mathrm{acac})_{2}\right]$ and $\left[\mathrm{PF}_{6}\right]^{-}$, cleanly affording $\left[\mathrm{B}\left(\mathrm{C}_{6} \mathrm{~F}_{5}\right)_{3} \mathrm{~F}\right]^{-}, \mathbf{9},{ }^{41}$ and $\mathrm{POF}_{3}, \mathbf{1 0} .{ }^{42}$ In addition, the reaction of $\left(\mathrm{C}_{6} \mathrm{~F}_{5}\right)_{3} \mathrm{~B}-\mathrm{O}-\mathrm{Ti}(\mathrm{acac})_{2}$ with $\left[\mathrm{PF}_{6}\right]^{-}$selectively produces $\mathbf{1 a}$ (detected by NMR analysis) in high yield, while the cation $\left[\mathrm{V}(\mathrm{acac})_{3}\right]^{+}$has been recognized (NMR, UV-Vis) from $\left(\mathrm{C}_{6} \mathrm{~F}_{5}\right)_{3} \mathrm{~B}-\mathrm{O}-\mathrm{V}(\mathrm{acac})_{2} /\left[\mathrm{PF}_{6}\right]^{-}$. Accordingly, the voltammetric profile of the mixture $\left(\mathrm{C}_{6} \mathrm{~F}_{5}\right)_{3} \mathrm{~B}-\mathrm{O}$ $\mathrm{V}(\mathrm{acac})_{2} /\left[\mathrm{N}^{n} \mathrm{Bu}_{4}\right]\left[\mathrm{PF}_{6}\right]$ displayed two distinct one-electron reductions at $+0.24 \mathrm{~V}$ and at $-2.02 \mathrm{~V}$, with features of chemical reversibility in the $\mathrm{CV}$ time scale. Such reductions have been attributed to $\mathrm{V}(\mathrm{IV}) / \mathrm{V}(\mathrm{III})$ and $\mathrm{V}(\mathrm{III}) / \mathrm{V}$ (II) couples. ${ }^{43}$ Coherently, the same pattern, due to the $\left[\mathrm{V}(\mathrm{acac})_{3}\right]^{+}$cation, has been found for $\left[\mathrm{V}(\mathrm{acac})_{3}\right]\left[\mathrm{MF}_{6}\right]$, $\mathbf{4 a}, \mathbf{b}$, in $\mathrm{CH}_{2} \mathrm{Cl}_{2} /\left[\mathrm{N}^{n} \mathrm{Bu}_{4}\right]\left[\mathrm{PF}_{6}\right]$. 


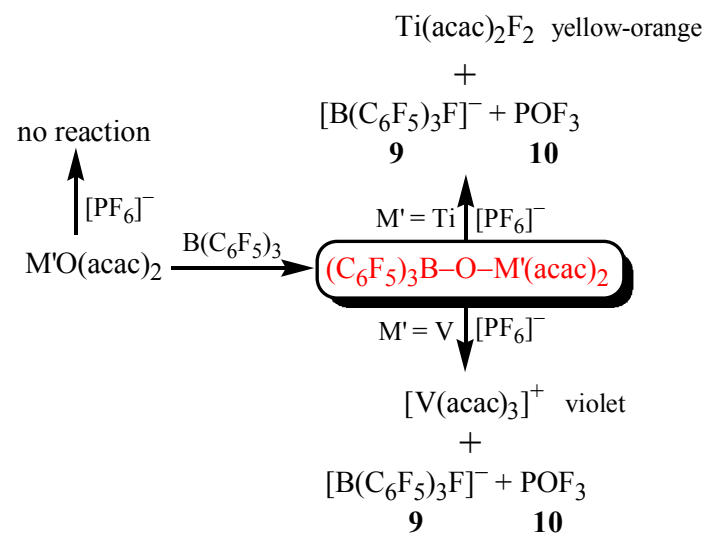

Scheme 5. Reactivity of $\left(\mathrm{C}_{6} \mathrm{~F}_{5}\right)_{3} \mathrm{~B}-\mathrm{O}-\mathrm{M}^{\prime}(\mathrm{acac})_{2}\left(\mathrm{M}^{\prime}=\mathrm{Ti}, \mathrm{V}\right)$ with $\left[\mathrm{NEt}_{4}\right]\left[\mathrm{PF}_{6}\right]$.

When freshly prepared 3 was dissolved into $\mathrm{CH}_{2} \mathrm{Cl}_{2} /\left[\mathrm{N}^{n} \mathrm{Bu}_{4}\right]\left[\mathrm{PF}_{6}\right]$, the voltammetric profile of the solution changed with time (Figure 2a), in accordance with the results reported in the previous Section (Scheme 1). More precisely, the CV recorded immediately after the dissolution showed a reversible reduction at $-0.57 \mathrm{~V}\left(i_{\mathrm{pa}} / i_{\mathrm{pc}}=0.88\right.$ for scan rate $\left.v=0.1 \mathrm{~V} \mathrm{~s}^{-1}\right)$, accompanied by an irreversible reduction at more negative potential $(-2.37 \mathrm{~V})$. Such electrochemical behaviour represents a significant proof for the existence of the [Ta-O-Ti] skeleton in $\mathbf{3}$; in fact, a very similar $\mathrm{CV}$ is exhibited by the [B-O-Ti] adduct $\left(\mathrm{C}_{6} \mathrm{~F}_{5}\right)_{3} \mathrm{~B}-\mathrm{O}-\mathrm{Ti}(\mathrm{acac})_{2}$ (Table 2). The absence of processes involving the $\left[\mathrm{TaF}_{6}\right]^{-}$anion in $\mathbf{3}$ is consistent with the observation that a solution of $\left[\mathrm{S}\left(\mathrm{NMe}_{2}\right)_{3}\right]\left[\mathrm{TaF}_{6}\right]^{22 \mathrm{~b}}$ in $\mathrm{CH}_{2} \mathrm{Cl}_{2} /\left[\mathrm{N}^{n} \mathrm{Bu}_{4}\right]\left[\mathrm{PF}_{6}\right]$ showed no reduction peaks until the solvent discharge occurring at $c a$. $-2.6 \mathrm{~V}^{44}$

The signals due to $\left[\mathrm{TaF}_{4}\left\{\mathrm{OTi}(\mathrm{acac})_{2}\right\}_{2}\right]^{+}$decreased their intensity within 20 minutes, while a new wave became evident at $-1.29 \mathrm{~V}$ (Figure 2a). This wave remained the only observable redox process after some hours, and was attributed to $\mathbf{1 a}$. In fact the $\mathrm{CV}$ trace of $\mathbf{1 a}$ in the range +1.4 to $-2.6 \mathrm{~V}$ is characterized by one monoelectronic reduction process at $-1.29 \mathrm{~V}$, complicated by a subsequent chemical reaction $\left(i_{\mathrm{pa}} / i_{\mathrm{pc}}=0.84\right.$ for scan rate $\left.v=0.1 \mathrm{~V} \mathrm{~s}^{-1}\right)$, see Figure $2 \mathrm{~b}$.

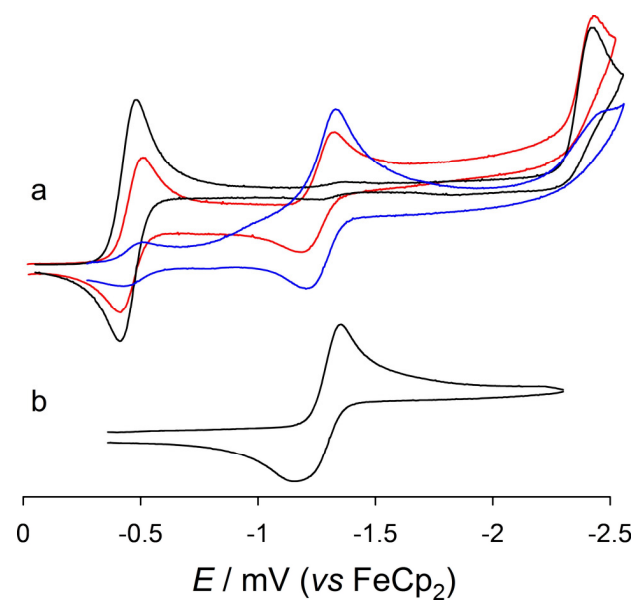

Figure 2. Cyclic voltammograms recorded at $\mathrm{Pt}$ electrode in $\mathrm{CH}_{2} \mathrm{Cl}_{2}$ solution of: a) 3 immediately after dissolution (black), after 10' (red), after 20' (blue); b) 1a. Supporting electrolyte: $\left[\mathrm{N}^{n} \mathrm{Bu}_{4}\right]\left[\mathrm{PF}_{6}\right]\left(0.2 \mathrm{~mol} \mathrm{dm}{ }^{-3}\right)$; scan rates $=0.1 \mathrm{~V} \mathrm{~s}^{-1}$.

In order to verify the number of electrons involved in the reduction process occurring at $-1.29 \mathrm{~V}$, a solution of 1a was subjected to controlled potential coulometry $\left(E_{\mathrm{w}}=-1.4 \mathrm{~V}\right)$. By monitoring the electrolysis progress with cyclic voltammetry, we noticed that the height of the cathodic peak at $-1.29 \mathrm{~V}$ decreased proportionally to the advancement of coulometry. Moreover a new anodic reversible peak at $-0.58 \mathrm{~V}$ and a cathodic irreversible peak at $-2.4 \mathrm{~V}$ appeared. The wave corresponding to the reduction of 1a completely disappeared after consumption of $0.5 \mathrm{~mol}$ of electrons per mole of complex.

The blue colour of the solution and the appearance of the reversible oxidation at $-0.58 \mathrm{~V}$ have suggested the formation of a $\mathrm{Ti}(\mathrm{III})$ species; otherwise the irreversible reduction at $-2.4 \mathrm{~V}$ has been tentatively assigned to $\left[\mathrm{Ti}(\mathrm{acac})_{2} \mathrm{~F}_{3}\right]^{-}$. As a matter of fact, a superimposable voltammetric profile in the negative scan $(0 /-2.6 \mathrm{~V})$ was obtained when the mixture 1a/TASF (TASF, $\left[\left(\mathrm{Me}_{2} \mathrm{~N}\right)_{3} \mathrm{~S}\right]\left[\mathrm{Me}_{3} \mathrm{SiF}_{2}\right]$, is a well-established $\mathrm{F}^{-}$transferer $\left.{ }^{45,22 \mathrm{~b}}\right)$, was examined by $\mathrm{CV}$ under the same experimental conditions.

In other words, the reduction of 1 a seems to occur according to Scheme 6: fluoride abstraction by $\mathbf{1 a}$ from the complex $\mathbf{1 a}^{-}$ presumably generates the $\mathrm{Ti}(\mathrm{III})$ complex $\mathrm{Ti}(\mathrm{acac})_{2} \mathrm{~F}$ and the hard to reduce $\mathrm{Ti}(\mathrm{IV})$ anion $\left[\mathrm{Ti}(\mathrm{acac})_{2} \mathrm{~F}_{3}\right]^{-}$. Attempts to isolate these species for further characterization were unsuccessful.

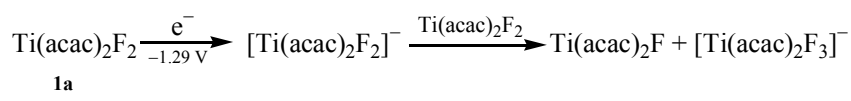

Scheme 6. Reduction of $\mathrm{Ti}(\mathrm{acac})_{2} \mathrm{~F}_{2}, \mathbf{1 a}$.

The voltammetric response of $\mathrm{Ti}(\mathrm{acac})_{2} \mathrm{Cl}_{2}, \mathbf{1 b}$, in $\mathrm{CH}_{2} \mathrm{Cl}_{2} /\left[\mathrm{N}^{n} \mathrm{Bu}_{4}\right]\left[\mathrm{PF}_{6}\right]$ solution showed one reversible reduction at $-0.69 \mathrm{~V}\left(i_{\mathrm{p}} \mathrm{a} / i_{\mathrm{p}} \mathrm{c}=0.9\right.$ at scan rate of $\left.0.1 \mathrm{~V} / \mathrm{s}\right)$. The intensity of this wave promptly decreased, while new reduction processes became evident at -0.93 and $-1.29 \mathrm{~V}$. We have assigned the reduction at $-1.29 \mathrm{~V}$ to the difluoride complex $1 \mathrm{a}$ and the reduction at $-0.93 \mathrm{~V}$ to the mixed halide $\mathrm{Ti}(\mathrm{acac})_{2} \mathrm{ClF}$, both formed by $\mathrm{F}^{-}$abstraction from the supporting electrolyte. Former investigation on the chemistry of $\mathbf{1 b}$ demonstrated the possibility of easy, partial or complete, replacement of chloride ligands in the presence of a potential fluoride source. ${ }^{46}$ It has to be noted that the voltammetric response of $\mathbf{1 b}$ in $\mathrm{CH}_{2} \mathrm{Cl}_{2} /\left[\mathrm{N}^{n} \mathrm{Bu}_{4}\right]\left[\mathrm{ClO}_{4}\right]$ solution remained unchanged for several hours and exhibited only the reduction at $-0.69 \mathrm{~V}$.

We attempted to detect short-lived $\mathrm{M}-\mathrm{O}-\mathrm{V}$ adducts in the course of the reactions of $\mathrm{MF}_{5}$ with $\mathrm{VO}(\mathrm{acac})_{2}$ (Scheme 2). Cyclic voltammograms were collected immediately after the mixing of the reagents in the electrochemical cell. A quick colour change of the solution from light-blue to deep-violet accompanied the dissolution of $\mathrm{MF}_{5}$, and the voltammetric profile typical of $\left[\mathrm{V}(\mathrm{acac})_{3}\right]^{+}$was observed. This fact points out that oxygen transfer from vanadium to $\mathrm{M}$ centre takes place readily, thus preventing the recognition of redox changes due to short-lived $\mathrm{M}-\mathrm{O}-\mathrm{V}$ adducts.

\section{Conclusions}

In this paper, we have described the chemistry of titanium(IV) and vanadium(IV) oxide bis-acetylacetonates, $\mathrm{M}^{\prime} \mathrm{O}(\mathrm{acac})_{2}$, with $\mathrm{TiX}_{4}(\mathrm{X}=\mathrm{F}, \mathrm{Cl}), \mathrm{MF}_{5}(\mathrm{M}=\mathrm{Nb}, \mathrm{Ta})$, and $\mathrm{NbCl}_{5}$, respectively. All of the reactions, driven by thermodynamic factors, take place with selective interchange of ligands between the different metal centres, and represent novel routes for the preparation of haloacetylacetonato or oxido-halide complexes of groups 4-5 metals. The interchange of ligands is presumably initiated by the formation of an oxido-bridged adduct, which could be detected ( $\mathrm{Ta}-\mathrm{O}-\mathrm{Ti}$ $a d d u c t)$ in the case of the reaction between $\mathrm{TaF}_{5}$ and $\mathrm{TiO}(\mathrm{acac})_{2}$. This feature has found support in the fact that compounds $\mathrm{M}^{\prime} \mathrm{O}(\mathrm{acac})_{2}$ do not undergo oxygen loss in the presence of $\left[\mathrm{PF}_{6}\right]^{-}$, unless they are preliminarily activated by coordination to a Lewis acid such as $\mathrm{B}\left(\mathrm{C}_{6} \mathrm{~F}_{5}\right)_{3}$.

Electrochemical analyses have assisted the characterization of the new compounds and have allowed the study of degradation pathways. The electrochemical outcomes demonstrate that the coordination of a Lewis acid to $\mathrm{MO}(\mathrm{acac})_{2}(\mathrm{M}=\mathrm{Ti}, \mathrm{V})$ enhances the 
tendency of the latter to be reduced. By a parallel study of the electrochemical behaviours of $\left(\mathrm{C}_{6} \mathrm{~F}_{5}\right)_{3} \mathrm{~B}-\mathrm{O}-\mathrm{Ti}(\mathrm{acac})_{2}$ and $\left[\mathrm{TaF}_{4}\left\{\mathrm{OTi}(\mathrm{acac})_{2}\right\}_{2}\right]\left[\mathrm{TaF}_{6}\right]$, dissolved into $\mathrm{CH}_{2} \mathrm{Cl}_{2} /\left[\mathrm{N}^{n} \mathrm{Bu}_{4}\right]\left[\mathrm{PF}_{6}\right]$, the quick formation of $\mathrm{Ti}(\mathrm{acac})_{2} \mathrm{~F}_{2}$ from the tantalum adduct has been ascertained. $\mathrm{V}$-containing intermediate products, analogous to $\left[\mathrm{TaF}_{4}\left\{\mathrm{OTi}(\mathrm{acac})_{2}\right\}_{2}\right]\left[\mathrm{TaF}_{6}\right]$, could not be recognized due to fast $O-$ transfer. A detailed description of the electrochemical behaviours of $\mathrm{TiO}(\mathrm{acac})_{2}$ and $\mathrm{Ti}(\mathrm{acac})_{2} \mathrm{X}_{2}(\mathrm{X}=\mathrm{F}, \mathrm{Cl})$ has been reported for the first time.

\section{Experimental Section}

\section{General Features}

All of the manipulations of air and/or moisture sensitive compounds were performed under atmosphere of pre-purified argon using standard Schlenk techniques. The reaction vessels were oven dried at $150{ }^{\circ} \mathrm{C}$ prior to use, evacuated $\left(10^{-2} \mathrm{mmHg}\right)$ and then filled with argon. $\mathrm{MX}_{5}(\mathrm{M}=\mathrm{Nb}, \mathrm{Ta}, \mathrm{X}=\mathrm{F} ; \mathrm{M}=\mathrm{Nb}, \mathrm{X}=\mathrm{Cl}), \mathrm{TiX}_{4}(\mathrm{X}=$ $\mathrm{F}, \mathrm{Cl}), \mathrm{M}^{\prime} \mathrm{O}(\mathrm{acac})_{2}(\mathrm{M}=\mathrm{Ti}, \mathrm{V})$ and $\left[\left(\mathrm{Me}_{2} \mathrm{~N}\right)_{3} \mathrm{~S}\right]\left[\mathrm{Me}_{3} \mathrm{SiF}_{2}\right](\mathrm{TASF})$ were commercial products (Sigma-Aldrich), stored under argon atmosphere as received and used without further purification. $\left[\mathrm{N}^{n} \mathrm{Bu}_{4}\right]\left[\mathrm{PF}_{6}\right]$ (Fluka, puriss. electrochemical grade), $\left[\mathrm{N}^{n} \mathrm{Bu}_{4}\right]\left[\mathrm{BPh}_{4}\right]$ (Sigma-Aldrich, 99\%) and $\left[\mathrm{N}^{n} \mathrm{Bu}_{4}\right]\left[\mathrm{ClO}_{4}\right]$ (Fluka, puriss. Electrochemical grade) were used as purchased. Ferrocene $\left(\mathrm{FeCp}_{2}\right.$, $\mathrm{Fc}),{ }^{47}\left(\mathrm{C}_{6} \mathrm{~F}_{5}\right)_{3} \mathrm{~B}-\mathrm{O}-\mathrm{V}(\mathrm{acac})_{2},{ }^{13}$ and $\left(\mathrm{C}_{6} \mathrm{~F}_{5}\right)_{3} \mathrm{~B}-\mathrm{O}-\mathrm{Ti}(\mathrm{acac})_{2}{ }^{13}$ were prepared according to the literature. Solvents were distilled before use under argon atmosphere from appropriate drying agents. Infrared spectra were recorded at $298 \mathrm{~K}$ either on FT IR-Perkin Elmer Spectrum One Spectrometer equipped with UATR sampling accessory, or on FT IR-Perkin Elmer Spectrum 100 Spectrometer equipped with CsI beam splitter. UV-VIS spectra were recorded with Perkin-Elmer Lambda EZ201 spectrophotometer at $293 \mathrm{~K} .{ }^{1} \mathrm{H}$, ${ }^{13} \mathrm{C}$ and ${ }^{19} \mathrm{~F}$ NMR spectra were recorded on Varian Gemini 200BB instrument at $293 \mathrm{~K}$, unless otherwise stated. Chemical shifts for ${ }^{1} \mathrm{H}$ and ${ }^{13} \mathrm{C}$ were referenced to the non-deuterated aliquot of the solvent; chemical shifts for ${ }^{19} \mathrm{~F}$ were referenced to external $\mathrm{CFCl}_{3}$; chemical shifts for ${ }^{31} \mathrm{P}$ were referenced to external $\mathrm{H}_{3} \mathrm{PO}_{4}$. Conductivity measurements were carried out on $\mathrm{CH}_{2} \mathrm{Cl}_{2}$ solutions $\mathrm{ca}$. $0.010 \mathrm{M}$ with Eutech Con 700 Instrument (cell constant $=1.0 \mathrm{~cm}^{-1}$ ), at 298 $\mathrm{K} .{ }^{48}$ Carbon and hydrogen analyses were performed on Carlo Erba mod. 1106 instrument. The content of niobium and tantalum was analyzed as $\mathrm{M}_{2} \mathrm{O}_{5}$, obtained by high temperature treatment of the solid sample with $\mathrm{HNO}_{3}$ solution, followed by calcination in a platinum crucible. The titanium content was determined spectrophotometrically by measuring the $410 \mathrm{~nm}$ absorbance of an aqueous solution after treatment with few drops of $30 \%$ aqueous $\mathrm{H}_{2} \mathrm{O}_{2}$. The chloride content was determined by the Mohr method ${ }^{49}$ on solutions prepared by dissolution of the solid in aqueous $\mathrm{KOH}$ at boiling temperature, followed by cooling down to room temperature and addition of $\mathrm{HNO}_{3}$ up to neutralization. ESI MS spectrum was recorded on Waters Micromass ZQ 4000 with sample dissolved in $\mathrm{CH}_{3} \mathrm{CN}$.

Unless otherwise indicated, electrochemical measurements were performed on $0.2 \mathrm{M}$ dichloromethane solutions of $\left[\mathrm{N}^{n} \mathrm{Bu}_{4}\right]\left[\mathrm{PF}_{6}\right]$ as supporting electrolyte. Cyclic voltammograms were performed with a Princeton Applied Research (PAR) 273A Potentiostat / Galvanostat, interfaced to a personal computer, employing PAR M270 Electrochemical Software. All measurements were carried out in a three-electrode home-built cell at room temperature $(20 \pm$ $5^{\circ} \mathrm{C}$ ). The working and the counterelectrode consisted of a platinum disk electrode and a platinum wire spiral, respectively, both sealed in a glass tube. A quasi-reference electrode of platinum was employed as reference. The Schlenk-type construction of the cell maintained anhydrous and anaerobic conditions. The cell was predried by prolonged heating under vacuum and filled with argon. A $0.2 \mathrm{M} \mathrm{CH}_{2} \mathrm{Cl}_{2}$ solution of $\left[\mathrm{N}^{n} \mathrm{Bu}_{4}\right]\left[\mathrm{PF}_{6}\right]$ under argon was then introduced into the cell and the working electrode was repeatedly cycled between the anodic and the cathodic limits of interest until no change in the charging current. The substrate was introduced to obtain a $1 \mathrm{mM}$ solution, and voltammograms were recorded at sweep rate $=100 \mathrm{mV} \mathrm{s}^{-1}$. After several voltammograms were obtained on the substrate solution, a small amount of ferrocene was added, and the voltammogram was repeated. The $E^{\circ}$ values of the analyzed compounds were determined placing the $E_{1 / 2}$ of the ferrocene couple at $0.0 \mathrm{~V}$.

Controlled potential coulometry was performed in H-shaped cell with anodic and cathodic compartments separated by a sinteredglass disk. The working macroelectrode was a platinum gauze; a platinum-spiral was used as the counterelectrode.

\section{Reactivity of $\mathrm{MF}_{5}(\mathrm{M}=\mathrm{Nb}, \mathrm{M}=\mathrm{Ta})$ with $\mathrm{TiO}(\mathrm{acac})_{2}$.}

1) Synthesis of $\mathrm{Ti}(\text { acac })_{2} \mathrm{~F}_{2}, 1 \mathrm{a}$, and $\mathrm{MOF}_{3}(\mathrm{M}=\mathrm{Nb}, 2 \mathrm{a} ; \mathrm{M}=$ Ta, 2b). A solution of $\mathrm{TiO}(\mathrm{acac})_{2}(0.131 \mathrm{~g}, 0.500 \mathrm{mmol})$ in $1,2-$ dichloroethane $(15 \mathrm{~mL})$ was treated with $\mathrm{MF}_{5}(\mathrm{M}=\mathrm{Nb}, \mathrm{Ta} ; 0.500$ $\mathrm{mmol})$. The mixture was stirred at room temperature for 12 hours. Analogous outcome was obtained by performing the reaction at reflux temperature for 4 hours. The resulting precipitate was filtered, thus the light-orange solution was layered with heptane and stored at $-30^{\circ} \mathrm{C}$. A yellow-orange crystalline precipitate of $\mathrm{Ti}(\mathrm{acac})_{2} \mathrm{~F}_{2}, \mathbf{1 a}^{15}(0.106 \mathrm{~g}, 75 \%$ yield $)$, was obtained after 3 days. Compound 1a was identified by elemental analysis, NMR spectroscopy and X-ray diffractometry. Anal. Calcd. for $\mathrm{C}_{10} \mathrm{H}_{14} \mathrm{~F}_{2} \mathrm{O}_{4} \mathrm{Ti}$ : $\mathrm{C}, 42.28 ; \mathrm{H}, 4.97 ; \mathrm{Ti}, 16.85$. Found (from the reaction with $\left.\mathrm{NbF}_{5}\right): \mathrm{C}, 42.49 ; \mathrm{H}, 4.63 ; \mathrm{Ti}, 17.02$. ${ }^{1} \mathrm{H}$ NMR $\left(\mathrm{CD}_{2} \mathrm{Cl}_{2}\right) \delta 5.93(\mathrm{~s}, 1 \mathrm{H}, \mathrm{CH}) ; 2.13(\mathrm{~s}, 6 \mathrm{H}, \mathrm{CH}) \mathrm{ppm} .{ }^{13} \mathrm{C}\left\{{ }^{1} \mathrm{H}\right\}$ NMR $\left(\mathrm{CD}_{2} \mathrm{Cl}_{2}\right) \delta 194.0(\mathrm{CO}) ; 107.0(\mathrm{CH}) ; 25.8\left(\mathrm{CH}_{3}\right)$ ppm. ${ }^{19} \mathrm{~F}$ NMR $\left(\mathrm{CD}_{2} \mathrm{Cl}_{2}\right) \delta 231.6 \mathrm{ppm}$. The reaction precipitate was washed with 1,2-dichloroethane $(3 \times 10 \mathrm{~mL})$, dried in vacuo and identified as $\mathrm{MOF}_{3}(\mathrm{M}=\mathrm{Nb}, \mathbf{2 a} ; \mathrm{M}=\mathrm{Ta}, \mathbf{2 b})$ by metal analysis and IR spectroscopy. ${ }^{17}$ 2a (yield 65\%). Anal. Calcd. for $\mathrm{F}_{3} \mathrm{NbO}$ : $\mathrm{Nb}$, 56.00. Found: $\mathrm{Nb}, 55.20$. IR (solid state): $v=994 \mathrm{~s}\left(v_{\mathrm{Nb}=\mathrm{O}}\right) \mathrm{cm}^{-1}$. 2b (yield 61\%). Anal. Calcd. for $\mathrm{F}_{3} \mathrm{OTa}$ : Ta, 71.26. Found: Ta, 69.92. IR (solid state): $v=1020 \mathrm{~s}\left(v_{\mathrm{Ta}=\mathrm{O}}\right) \mathrm{cm}^{-1}$.

2) Isolation and characterization of $\left[\mathrm{TaF}_{4}\left\{\mathrm{OTi}(\mathbf{a c a c})_{2}\right\}_{2}\right]\left[\mathrm{TaF}_{6}\right], 3$. A NMR tube was charged with $\mathrm{TaF}_{5}(0.055 \mathrm{~g}, 0.200 \mathrm{mmol}), \mathrm{TiO}(\mathrm{acac})_{2}(0.052 \mathrm{~g}, 0.200 \mathrm{mmol})$ and $\mathrm{CD}_{2} \mathrm{Cl}_{2}(0.70 \mathrm{~mL})$, in the order given. The tube was sealed and shaken in order to homogenize the content. After 30 minute, NMR analysis of the resulting yellow solution pointed the formation of $\mathbf{3}$. ${ }^{1} \mathrm{H}$ NMR $\left(\mathrm{CD}_{2} \mathrm{Cl}_{2}\right) \delta 6.22(\mathrm{~s}, 1 \mathrm{H}, \mathrm{CH}) ; 2.27\left(\mathrm{~s}, 6 \mathrm{H}, \mathrm{CH}_{3}\right) \mathrm{ppm}$. ${ }^{13} \mathrm{C}\left\{{ }^{1} \mathrm{H}\right\} \operatorname{NMR}\left(\mathrm{CD}_{2} \mathrm{Cl}_{2}\right) \delta 194.4(\mathrm{CO}) ; 109.7(\mathrm{CH}) ; 25.7\left(\mathrm{CH}_{3}\right)$ ppm. ${ }^{19} \mathrm{~F}$ NMR $\left(\mathrm{CD}_{2} \mathrm{Cl}_{2}\right) \delta 38.4\left(\mathrm{~s}, \mathrm{Ta}_{6}\right)$ ppm. Conversion of 3 into 1 a was completed after heating the tube at $50^{\circ} \mathrm{C}$ for 4 hours.

A $\mathrm{CH}_{2} \mathrm{Cl}_{2}$ solution $(28 \mathrm{~mL}$ ) of $\mathbf{3}$ was obtained from equimolar amounts of $\mathrm{TaF}_{5}$ and $\mathrm{TiO}(\mathrm{acac})_{2}(0.800 \mathrm{mmol})$. Conductivity analysis was as follows: $\Lambda_{M}=6.0 \mathrm{~S} \mathrm{~cm}^{2} \mathrm{~mol}^{-1}$. An aliquot $(0.3 \mathrm{~mL})$ of the solution, mixed with $\mathrm{CD}_{2} \mathrm{Cl}_{2}(0.4 \mathrm{~mL})$, was analyzed by ${ }^{1} \mathrm{H}$ $\mathrm{NMR}$, confirming the formation of $\mathbf{3}$. The remaining portion of the solution was dried under vacuo thus giving a pale-orange powder. Yield: $0.353 \mathrm{~g}, 82 \%$. Anal. Calcd. for $\mathrm{C}_{20} \mathrm{H}_{28} \mathrm{~F}_{10} \mathrm{O}_{10} \mathrm{Ta}_{2} \mathrm{Ti}_{2}$ : C, 22.32; $\mathrm{H}, 2.62 ; \mathrm{Ti}, 8.90$. Found: C, 22.05; H, 2.41; Ti, 9.06. IR (solid state): $v=1530 \mathrm{vs}\left(v_{\mathrm{C}=\mathrm{O}}\right), 1422 \mathrm{~m}, 1293 \mathrm{~s}, 1033 \mathrm{~m}, 933 \mathrm{~m}, 811 \mathrm{~m}-\mathrm{s}, 782 \mathrm{~s}$, $670 \mathrm{vs} \mathrm{cm}^{-1}$.

Reactivity of $\mathrm{MF}_{5}\left(\mathrm{M}=\mathrm{Nb}\right.$, Ta) with $\mathrm{VO}(\mathrm{acac})_{2}$. Synthesis of $\left[\mathrm{V}(\mathrm{acac})_{3}\right]\left[\mathrm{MF}_{6}\right](\mathrm{M}=\mathrm{Nb}, \mathbf{4 a} ; \mathbf{M}=\mathbf{T a}, \mathbf{4 b})$. A solution of $\mathrm{VO}(\mathrm{acac})_{2}(0.215 \mathrm{~g}, 0.811 \mathrm{mmol})$ in 1,2-dichloroethane $(15 \mathrm{~mL})$ was added of $\mathrm{NbF}_{5}(0.154 \mathrm{~g}, 0.820 \mathrm{mmol})$. After $6 \mathrm{~h}$ stirring at room temperature, the resulting dark-violet solution was separated from a dark precipitate by filtration. IR analysis on the precipitate suggested the presence of a mixture of non identifiable products. The solution was concentrated $(2 \mathrm{~mL})$, layered with pentane and stored at $-30^{\circ} \mathrm{C}$. The product $\mathbf{4 a}$ was obtained as a 
microcrystalline dark-violet material after 4 days. Yield: $0.212 \mathrm{~g}$, 71\%. Anal. Calcd. for $\mathrm{C}_{15} \mathrm{H}_{21} \mathrm{~F}_{6} \mathrm{NbO}_{6} \mathrm{~V}: \mathrm{C}, 32.45 ; \mathrm{H}, 3.81$. Found: C, 32.13; H, 3.90. IR (solid state): $v=1520 \mathrm{vs}\left(v_{\mathrm{C}=\mathrm{O}}\right), 1421 \mathrm{~m}-\mathrm{s}$, $1359 \mathrm{~m}, 1280 \mathrm{~s}, 1168 \mathrm{w}, 1030 \mathrm{~m}, 934 \mathrm{~m}, 780 \mathrm{~m}, 664 \mathrm{~s} \mathrm{~cm}^{-1} .{ }^{1} \mathrm{H}$ NMR $\left(\mathrm{CDCl}_{3}\right) \delta 6.38(\mathrm{~s}, 1 \mathrm{H}, \mathrm{CH}) ; 2.35\left(\mathrm{~s}, 6 \mathrm{H}, \mathrm{CH}_{3}\right) \mathrm{ppm} .{ }^{19} \mathrm{~F} \mathrm{NMR}$ $\left(\mathrm{CDCl}_{3}, 183 \mathrm{~K}\right) \delta 103.2 \mathrm{ppm}\left(\operatorname{decet}^{1}{ }^{l} J_{\mathrm{NbF}}=350 \mathrm{~Hz}, \mathrm{Nb} F_{6}{ }^{-}\right) \mathrm{ppm}$. UV-Vis $\left(\mathrm{CH}_{2} \mathrm{Cl}_{2}\right): \lambda_{\max }=560 \mathrm{~nm} . \Lambda_{M}=8.7 \mathrm{~S} \mathrm{~cm}^{2} \mathrm{~mol}^{-1}$. ESI-MS $\left(\mathrm{ES}^{+}\right): 348\left[\mathrm{M}^{+}, 25 \%\right], 249\left[\mathrm{M}^{+}\right.$-acac, $\left.100 \%\right] \mathrm{m} / \mathrm{z}$.

Compound 4b was obtained by a procedure analogous to that described for the synthesis of $\mathbf{4 a}$, from $\mathrm{VO}(\mathrm{acac})_{2}(0.250 \mathrm{~g}, 0.943$ mmol) and $\mathrm{TaF}_{5}(0.260 \mathrm{~g}, 0.942 \mathrm{mmol})$. Yield: $0.273 \mathrm{~g}, 68 \%$. Anal. Calcd. for $\mathrm{C}_{15} \mathrm{H}_{21} \mathrm{~F}_{6} \mathrm{O}_{6} \mathrm{TaV}$ : C, 28.01; H, 3.29. Found: $\mathrm{C}$, 27.75; H, 3.24. IR (solid state): $v=1521 \mathrm{vs}\left(v_{\mathrm{C}=0}\right), 1419 \mathrm{~s}, 1359 \mathrm{~m}$, $1281 \mathrm{vs}, 1168 \mathrm{w}, 1031 \mathrm{~s}, 934 \mathrm{~s}, 780 \mathrm{~ms}, 663 \mathrm{vs} \mathrm{cm}^{-1} .{ }^{1} \mathrm{H}$ NMR $\left(\mathrm{CDCl}_{3}\right) \delta 6.33(\mathrm{~s}, 1 \mathrm{H}, \mathrm{CH}) ; 2.33\left(\mathrm{~s}, 6 \mathrm{H}, \mathrm{CH}_{3}\right) \mathrm{ppm} .{ }^{19} \mathrm{~F}$ NMR $\left(\mathrm{CDCl}_{3}\right) \delta 42.6 \mathrm{ppm}\left(\mathrm{s}, \mathrm{Ta} F_{6}^{-}\right) \mathrm{ppm}$. UV-Vis $\left(\mathrm{CH}_{2} \mathrm{Cl}_{2}\right): \lambda_{\max }=$ $560 \mathrm{~nm} . \Lambda_{M}=6.3 \mathrm{~S} \mathrm{~cm}^{2} \mathrm{~mol}^{-1}$.

Reactivity of $\mathrm{NbCl}_{5}$ with $\mathrm{TiO}(\mathrm{acac})_{2}$. Synthesis of [NbO(acac)Cl $\mathrm{Cl}_{2}, \mathbf{5}$, and $\mathrm{Ti}_{2}(\mathrm{acac})_{2}\left(\mu-\mathrm{Cl}_{2} \mathrm{Cl}_{4}, 6\right.$. A suspension of $\mathrm{NbCl}_{5}(0.115 \mathrm{~g}, 0.426 \mathrm{mmol})$ in $\mathrm{CH}_{2} \mathrm{Cl}_{2}(12 \mathrm{~mL})$ was treated with $\mathrm{TiO}(\mathrm{acac})_{2}(0.112 \mathrm{~g}, 0.427 \mathrm{mmol})$. The mixture was stirred at room temperature for 3 hours, during which progressive turning of the colour to orange was observed. Then the mixture was filtered in order to separate a yellow solid from an orange solution. The solid was washed with heptane $(2 \times 10 \mathrm{~mL})$, thus it was identified as 5 (yield $69 \%$ ) on the basis of IR spectroscopy ${ }^{29}$ and elemental analysis. Anal. Calcd. for $\mathrm{C}_{5} \mathrm{H}_{7} \mathrm{Cl}_{2} \mathrm{NbO}_{3}: \mathrm{C}, 21.53 ; \mathrm{H}, 2.53 ; \mathrm{Cl}$, 25.42; Nb, 33.31. Found: C, 21.78; H, 2.39; Cl, 25.29; Nb, 33.13. The solution was layered with pentane in a Schlenk tube. Orange crystals of $\mathbf{6}$ were obtained after storing the Schlenk for 3 days at $-30^{\circ} \mathrm{C}$. Yield: $0.072 \mathrm{~g}, 67 \%$. The identity of 6 was established by $\mathrm{X}$-ray analysis (on a single crystal) ${ }^{50,51}$ and IR and NMR spectroscopy. ${ }^{51}$

Reactivity of $\mathrm{TiX}_{4}(\mathrm{X}=\mathrm{F}, \mathrm{Cl})$ with $\mathrm{TiO}(\mathrm{acac})_{2}$. Synthesis of $\mathrm{Ti}(\text { acac })_{2} \mathrm{X}_{2}(\mathrm{X}=\mathrm{F}, 1 \mathrm{a} ; \mathrm{X}=\mathrm{Cl}, \mathbf{1 b})$ and $\mathrm{TiOX}_{2}(\mathrm{X}=\mathrm{F}, \mathbf{7 a} ; \mathrm{X}=$ Cl, $7 \mathbf{b})$. $\mathrm{TiX}_{4}(0.700 \mathrm{mmol})$ was added to a solution of $\mathrm{TiO}(\mathrm{acac})_{2}$ $(0.183 \mathrm{~g}, 0.698 \mathrm{mmol})$ in 1,2-dichloroethane $(15 \mathrm{~mL})$. The mixture from $\mathrm{TiF}_{4}$ was stirred overnight at room temperature, while the one from $\mathrm{TiCl}_{4}$ was heated at reflux temperature for 2 hours. The final mixture was filtered in order to separate a solution from a solid. The solid was washed with 1,2-dichloroethane $(3 \times 10 \mathrm{~mL})$ and then dried under vacuo. IR spectroscopy ${ }^{52,53}$ and Ti analysis (Anal. Calcd. for $\mathrm{F}_{2} \mathrm{OTi}$ 46.99, found 46.60; Anal. Calcd. for $\mathrm{Cl}_{2} \mathrm{OTi} 35.52$, found 35.33 ) on the solid pointed out the formation of $7 \mathbf{a}, \mathbf{b}$ in high yield ( $c a .80 \%$ ). The light-orange solution was dried under vacuo, thus giving a residue of $\mathrm{Ti}(\mathrm{acac})_{2} \mathrm{X}_{2}$. Yield: $0.155 \mathrm{~g}, 78 \%$ (1a); 0.184 g, 83\% (1b). Compounds 1a,b were identified by elemental analysis, ${ }^{1} \mathrm{H}$ NMR spectroscopy ${ }^{15}$ and Xray diffractometry (the crystals were obtained from dichloromethane solutions layered with pentane and stored at -30 $\left.{ }^{\circ} \mathrm{C}\right) .{ }^{54}$ Anal. Calcd. for $\mathrm{C}_{10} \mathrm{H}_{14} \mathrm{~F}_{2} \mathrm{O}_{4} \mathrm{Ti}$ (1a): C, 42.28; H, 4.97; Ti, 16.85. Found: $\mathrm{C}, 42.14 ; \mathrm{H}, 4.83$; Ti, 16.39. Anal. Calcd. for $\mathrm{C}_{10} \mathrm{H}_{14} \mathrm{Cl}_{2} \mathrm{O}_{4} \mathrm{Ti}(\mathbf{1 b}): \mathrm{C}, 37.89 ; \mathrm{H}, 4.45 ; \mathrm{Cl}, 22.37 ; \mathrm{Ti}, 15.10$. Found: C, 37.63; H, 4.67; Cl, 22.19; Ti, 15.21.

Reactivity of $\mathrm{TiX}_{4}(\mathrm{X}=\mathrm{F}, \mathrm{Cl})$ with $\mathrm{VO}(\mathrm{acac})_{2}$. Synthesis of $\mathrm{Ti}(\text { acac })_{2} \mathrm{X}_{2}(\mathrm{X}=\mathrm{F}, \mathbf{1 a} ; \mathrm{X}=\mathrm{Cl}, 1 \mathrm{~b}), \mathrm{Ti}_{2}(\mathrm{acac})_{2}(\mu-\mathrm{Cl})_{2} \mathrm{Cl}_{4}, 6$, and $\mathbf{V O X}_{\mathbf{2}}(\mathbf{X}=\mathbf{F}, \mathbf{8 a} ; \mathbf{X}=\mathbf{C l}, \mathbf{8 b})$. $\mathrm{TiX}_{4}(0.700 \mathrm{mmol})$ was added to a solution of $\mathrm{VO}(\mathrm{acac})_{2} \quad(0.185 \mathrm{~g}, \quad 0.698 \mathrm{mmol})$ in $1,2-$ dichloroethane $(15 \mathrm{~mL})$. The mixture from $\mathrm{TiF}_{4}$ was stirred overnight at room temperature, while the one from $\mathrm{TiCl}_{4}$ was heated at reflux temperature for 2 hours. The final mixture was filtered in order to separate a solution from a solid. The latter was identified as $\mathrm{VOX}_{2}, \mathbf{8 a}, \mathbf{b}$, by IR spectroscopy ${ }^{35,55}$ and, in the case of $\mathbf{8 b}$, by $\mathrm{Cl}$ analysis (anal. calcd. for $\mathrm{Cl}_{2} \mathrm{OV}: \mathrm{Cl}, 51.44$; found: $\mathrm{Cl}$,
50.70). The solution was layered with heptane in a Schlenk tube and maintained at $-30{ }^{\circ} \mathrm{C}$ for one week. Thus compounds $\mathbf{1 a , b}$ were recovered as crystalline yellow solids. Yield: $0.161 \mathrm{~g}, 81 \%$ (1a); 0.157 g, 79\% (1b). Compound 1a was identified by elemental analysis, ${ }^{1} \mathrm{H}$ and ${ }^{19} \mathrm{~F}$ NMR spectroscopy, while compound $\mathbf{1 b}$ was identified by elemental analysis, ${ }^{1} \mathrm{H}$ NMR and single-crystal X-ray diffractometry. Anal. Calcd. for $\mathrm{C}_{10} \mathrm{H}_{14} \mathrm{~F}_{2} \mathrm{O}_{4} \mathrm{Ti}$ (1a): C, 42.28; H, 4.97; Ti, 16.85. Found: C, 42.83; H, 5.06; Ti, 16.69. Anal. Calcd. for $\mathrm{C}_{10} \mathrm{H}_{14} \mathrm{Cl}_{2} \mathrm{O}_{4} \mathrm{Ti}(1 \mathbf{b})$ : C, 37.89; $\mathrm{H}, 4.45 ; \mathrm{Cl}$, 22.37; Ti, 15.10. Found: C, 38.01; H, 4.49; Cl, 22.03; Ti, 14.90 .

In a different experiment, $\mathrm{TiCl}_{4}(1.200 \mathrm{mmol})$ was added to a solution of $\mathrm{VO}(\mathrm{acac})_{2}(0.600 \mathrm{mmol})$ in dichloromethane $(10 \mathrm{~mL})$. The mixture was stirred for 4 hours at room temperature. The final mixture was filtered in order to separate a solution from a solid. The solid was identified as $\mathbf{8 b}$ by $\mathrm{IR}^{55}$ and $\mathrm{Cl}$ analysis (anal. calcd. for $\mathrm{Cl}_{2} \mathrm{OV}$ : $\mathrm{Cl}, 51.44$; found: $\mathrm{Cl}, 50.53$ ). The filtrated solution was layered with heptane in a Schlenk tube. Thus compound $\mathrm{Ti}_{2}(\mathrm{acac})_{2}(\mu-\mathrm{Cl})_{2} \mathrm{Cl}_{4}, \mathbf{6}$, was obtained as a crystalline solid after storing the Schlenk at $-30^{\circ} \mathrm{C}$ for one week. Yield: $0.094 \mathrm{~g}, 62 \%$. The identity of the product 6 was ascertained by means of elemental analysis, IR, NMR ${ }^{51}$ and X-ray. Anal. Calcd. for $\mathrm{C}_{10} \mathrm{H}_{14} \mathrm{Cl}_{6} \mathrm{O}_{4} \mathrm{Ti}_{2}$ : C, 23.71; $\mathrm{H}, 2.79 ; \mathrm{Cl}, 41.98 ; \mathrm{Ti}, 18.89$. Found: C, 23.64; H, 2.92; Cl, 41.73; Ti, 18.96.

\section{Reactivity of $\left(\mathrm{C}_{6} \mathrm{~F}_{5}\right)_{3} \mathrm{~B}-\mathrm{O}-\mathrm{M}^{\prime}(\mathbf{a c a c})_{2} \quad\left(\mathrm{M}^{\prime}=\mathrm{Ti}, \mathrm{V}\right)$ with $\left[\mathrm{NEt}_{4}\right]\left[\mathrm{PF}_{6}\right]$.}

1) $\mathbf{M}^{\prime}=\mathrm{V}$. Formation of $\left[\mathrm{V}(\mathrm{acac})_{3}\right]^{+},\left[\mathrm{B}\left(\mathrm{C}_{6} \mathrm{~F}_{5}\right)_{3} \mathrm{~F}\right]^{-}, 9$, and $\mathbf{P O F}_{3}, \mathbf{1 0}$. A green solution of the complex $\left(\mathrm{C}_{6} \mathrm{~F}_{5}\right)_{3} \mathrm{~B}-\mathrm{O}-\mathrm{V}(\mathrm{acac})_{2}$ $(0.350 \mathrm{~g}, 0.450 \mathrm{mmol})$ in toluene $(8 \mathrm{~mL})$ was treated with $\left[\mathrm{NEt}_{4}\right]\left[\mathrm{PF}_{6}\right](0.125 \mathrm{~g}, 0.454 \mathrm{mmol})$. The mixture was stirred at room temperature for 30 minutes, and progressive turning to darkviolet was noticed. The final mixture was filtered in order to remove insoluble material, thus a dark-violet solution was obtained. The cation $\left[\mathrm{V}(\mathrm{acac})_{3}\right]^{+}$was clearly identified by electrochemistry (Table 2) and UV-Vis spectroscopy (intense band at $560 \mathrm{~nm}){ }^{27}$

In a different experiment, $\left[\mathrm{NEt}_{4}\right]\left[\mathrm{PF}_{6}\right](0.150 \mathrm{mmol})$ was added to a solution of $\left(\mathrm{C}_{6} \mathrm{~F}_{5}\right)_{3} \mathrm{~B}-\mathrm{O}-\mathrm{V}(\mathrm{acac})_{2}(0.150 \mathrm{mmol})$ and benzene $\left(\mathrm{C}_{6} \mathrm{H}_{6}, 0.150 \mathrm{mmol}\right)$ in $\mathrm{CDCl}_{3}(0.70 \mathrm{~mL})$ in a NMR tube. The tube was sealed and shaken in order to homogenize the content. After 3 hours, NMR analysis was carried out on the dark-violet mixture. ${ }^{1} \mathrm{H} \mathrm{NMR}\left(\mathrm{CDCl}_{3}\right) \delta 6.30(\mathrm{~s}, 1 \mathrm{H}, \mathrm{CH}), 2.40\left(\mathrm{~s}, 6 \mathrm{H}, \mathrm{CH}_{3}\right) \mathrm{ppm}$ ([V(acac $\left.)_{3}\right]^{+} ; 40 \%$ yield relative to $\left.\mathrm{C}_{6} \mathrm{H}_{6}\right) .{ }^{19} \mathrm{~F} \mathrm{NMR}\left(\mathrm{CDCl}_{3}\right) \delta$ $-88.6\left(\mathrm{~d},{ }^{1} \mathrm{~J}_{\mathrm{PF}}=1073 \mathrm{~Hz}, \mathrm{PO} F_{3}\right) ;-136.5,-161.4,-166.0[\mathrm{~s}$, $\left.\mathrm{B}\left(\mathrm{C}_{6} F_{5}\right)_{3} \mathrm{~F}^{-}\right] ;-189.9$ [br, $\left.\mathrm{B}\left(\mathrm{C}_{6} \mathrm{~F}_{5}\right)_{3} F^{-}\right]$ppm. ${ }^{31} \mathrm{P}$ NMR $\left(\mathrm{CDCl}_{3}\right) \delta$ $-33.9\left(\mathrm{q},{ }^{1} \mathrm{~J}_{\mathrm{PF}}=1072 \mathrm{~Hz}, P \mathrm{OF}_{3}\right) \mathrm{ppm}$.

2) $\mathrm{M}^{\prime}=$ Ti. Formation of $\mathrm{Ti}(\operatorname{acac})_{2} \mathrm{~F}_{2}, 1 \mathrm{a},\left[\mathrm{B}\left(\mathrm{C}_{6} \mathbf{F}_{5}\right)_{3} \mathbf{F}\right]^{-}, 9$, and $\mathbf{P O F}_{3}, \mathbf{1 0}$. The reaction of $\left[\mathrm{NEt}_{4}\right]\left[\mathrm{PF}_{6}\right](0.150 \mathrm{mmol})$ with $\left(\mathrm{C}_{6} \mathrm{~F}_{5}\right)_{3} \mathrm{~B}-$ $\mathrm{O}-\mathrm{V}(\mathrm{acac})_{2}(0.150 \mathrm{mmol})$ was performed in $\mathrm{CDCl}_{3}(0.70 \mathrm{~mL})$ in the presence of benzene $\left(\mathrm{C}_{6} \mathrm{H}_{6}, 0.150 \mathrm{mmol}\right)$, by the same procedure as that described for $\left(\mathrm{C}_{6} \mathrm{~F}_{5}\right)_{3} \mathrm{~B}-\mathrm{O}-\mathrm{V}(\mathrm{acac})_{2} /\left[\mathrm{NEt}_{4}\right]\left[\mathrm{PF}_{6}\right] .{ }^{1} \mathrm{H},{ }^{19} \mathrm{~F}$ and ${ }^{31} \mathrm{P}$ NMR analyses on the light-orange solution pointed out the clean formation of $\mathbf{1 a}\left(88 \%\right.$ yield relative to $\left.\mathrm{C}_{6} \mathrm{H}_{6}\right), \mathbf{9}$ and $\mathbf{1 0}$.

X-ray Crystallographic Study. Crystal data and collection details for $\mathrm{Ti}(\mathrm{acac})_{2} \mathrm{~F}_{2} \cdot 0.5 \mathrm{C}_{2} \mathrm{H}_{4} \mathrm{Cl}_{2}, \mathbf{1} \mathbf{a} \cdot 0.5 \mathrm{C}_{2} \mathrm{H}_{4} \mathrm{Cl}_{2}$, are reported in Table 3. The diffraction experiments were carried out on a Bruker APEX II diffractometer equipped with a CCD detector and using Mo-K $\alpha$ radiation. Data were corrected for Lorentz polarization and absorption effects (empirical absorption correction SADABS) ${ }^{56}$ Structures were solved by direct methods and refined by fullmatrix least-squares based on all data using $F^{2} .{ }^{57}$ All nonhydrogen atoms were refined with anisotropic displacement parameters. H-atoms were placed in calculated positions and treated isotropically using the 1.2 fold $U_{\text {iso }}$ value of the parent atom except methyl protons, which were assigned the 1.5 fold $U_{\text {iso }}$ 
value of the parent $\mathrm{C}$-atom. The $\mathrm{C}_{2} \mathrm{H}_{4} \mathrm{Cl}_{2}$ unit is located on an inversion centre and only half of a molecule is independent.

Table 3. Crystal data and experimental details for $\mathbf{1 a} \cdot 0.5 \mathrm{C}_{2} \mathrm{H}_{4} \mathrm{Cl}_{2}$.

\begin{tabular}{|c|c|}
\hline Formula & $\mathrm{C}_{11} \mathrm{H}_{16} \mathrm{ClF}_{2} \mathrm{O}_{4} \mathrm{Ti}$ \\
\hline$F w$ & 333.59 \\
\hline $\mathrm{T}, \mathrm{K}$ & $100(2)$ \\
\hline$\lambda, \AA$ & 0.71073 \\
\hline Crystal system & Monoclinic \\
\hline Space group & $P 2_{1} / n$ \\
\hline$a, \AA$ & $7.348(2)$ \\
\hline$b, \AA$ & $15.929(5)$ \\
\hline$c, \AA$ & $12.843(4)$ \\
\hline$\beta,^{\circ}$ & $91.637(4)$ \\
\hline Cell Volume, $\AA^{3}$ & $1502.6(9)$ \\
\hline $\mathrm{Z}$ & 4 \\
\hline$D_{c}, \mathrm{~g} \mathrm{~cm}^{-3}$ & 1.475 \\
\hline$\mu, \mathrm{mm}^{-1}$ & 0.774 \\
\hline $\mathrm{F}(000)$ & 684 \\
\hline Crystal size, $\mathrm{mm}$ & $0.23 \times 0.21 \times 0.15$ \\
\hline$\theta$ limits, ${ }^{\circ}$ & $2.04-26.00$ \\
\hline Reflections collected & 7195 \\
\hline Independent reflections & $2926\left[R_{\mathrm{int}}=0.0486\right]$ \\
\hline Data / restraints / parameters & $2926 / 2 / 176$ \\
\hline Goodness on fit on $\mathrm{F}^{2}$ & 1.210 \\
\hline$R_{1}(I>2 \sigma(I))$ & 0.1051 \\
\hline$w R_{2}$ (all data) & 0.2550 \\
\hline Largest diff. peak and hole, e $\AA^{-3}$ & $1.432 /-1.209$ \\
\hline
\end{tabular}

CCDC 782632 contains the supplementary crystallographic data for 1a. These data can be obtained free of charge from The Cambridge Crystallographic Data Centre via www.ccdc.cam.ac.uk/data request/cif.

Supporting Information. Infrared spectra (solid state) of $\mathrm{TiO}(\mathrm{acac})_{2}, \quad \mathrm{VO}(\mathrm{acac})_{2}, \quad\left[\mathrm{TaF}_{4}\left\{\mathrm{OTi}(\mathrm{acac})_{2}\right\}_{2}\right]\left[\mathrm{TaF}_{6}\right], \quad \mathbf{3}$, $\left[\mathrm{V}(\mathrm{acac})_{3}\right]\left[\mathrm{MF}_{6}\right](\mathrm{M}=\mathrm{Nb}, \mathbf{4 a} ; \mathrm{M}=\mathrm{Ta}, \mathbf{4 b})$.

\section{Acknowledgements}

The authors thank the Ministero dell'Istruzione, dell'Università e della Ricerca (PRIN 2009 project: 'New strategies for the control of reactions: interactions of molecular fragments with metallic sites in unconventional species') for financial support.

\section{References and Notes}

1 a) Comprehensive Coordination Chemistry II, J. A. McCleverty and T. J. Meyer, Eds., Elsevier, Amsterdam, 2004. b) Comprehensive Organometallic Chemistry, E. W. Abel, F. G. A. Stone and G. Wilkinson, Pergamon, Oxford, 1995. c) F. Bottomley and L. Sutin, Adv. Organomet. Chem., 1988, 28, 339-396.

2 a) A. Ishikawa, Y. Nakao, H. Sato and S. Sakaki, Inorg. Chem., 2009, 48, 8154-8163; b) K. C. Fortner, D. S. Laitar, J. Muldoon, L. Pu, S. B. Braun-Sand, O. Wiest and S. N. Brown, J. Amer. Chem. Soc., 2007, 129, 588-600; c) P. Roussel, R. Boaretto, A. J. Kingsley, N. W. Alcock and P. Scott, J. Chem. Soc., Dalton Trans., 2002, 1423-1428; d) M. Mazzanti, C. Floriani, A. Chiesi-Villa and C. Guastini, Inorg. Chem., 1986, 25, 4158-4164.

3 G. Barrado, L. Doerrer, M. L. H. Green and M. A. Leech, J. Chem. Soc., Dalton Trans., 1999, 1061-1066, and references therein.

4 a) V. N. Nemykin and P. Basu, Inorg. Chem., 2005, 44, 7494-7502; b) S. Bhattacharyya, I. Chakraborty, B. K. Dirghangi and A. Chakravorty, Inorg. Chem., 2001, 40, 286-293.

5 a) R. H. Holm and J. P. Donahue, Polyhedron, 1993, 12, 571-589; b) R.H. Holm, Chem. Rev., 1987, 87, 1401-1449.

6 S. K. Mandal and H. W. Roesky, Acc. Chem. Res., 2010, 43, 248 259.

7 The pentafluorides of niobium and tantalum have tetranuclear structures in the solid state (ref. 8a) while the corresponding chlorides are dinuclear in the solid state and mononuclear in the vapour phase (ref. 8b). For sake of simplicity, these compounds will be mentioned by the empirical formulas $\mathrm{MX}_{5}$ throughout this paper

8 a) A. J. Edwards, J. Chem. Soc., 1964, 3714-3718. b) A. F. Wells, Structural Inorganic Chemistry, 5th Ed., Clarendon Press, Oxford, 1993.

9 F. Marchetti and G. Pampaloni, Chem. Commun., 2012, 48, 635-653, and references cited therein.

10 a) F. Marchetti, G. Pampaloni and S. Zacchini, Dalton Trans., 2008, 7026-7035; b) F. Marchetti, G. Pampaloni and S. Zacchini, Chem. Commun., 2008, 3651-3653; c) F. Marchetti, G. Pampaloni and S. Zacchini, Dalton Trans., 2009, 6759-6772.

11 Titanium(IV) oxide bis-acetylacetonate is dinuclear in the solid state, bearing two Ti-O-Ti units (ref. 12). For sake of simplicity, such compound will be mentioned by the empirical formula $\mathrm{TiO}(\mathrm{acac})_{2}$ throughout this paper.

12 G. D. Smith and C. N. Caughlan, J. A. Campbell, Inorg. Chem., 1972, 11, 2989-2993.

13 J. R. Galsworthy, M. L. H. Green, M. Müller and K. Prout, J. Chem. Soc., Dalton Trans., 1997, 1309-1313.

14 All of the compounds found as products in the reactions described in this paper have been numerated, while starting materials have not. Products 1a,b, 2a,b, 5-10 were previously obtained by different routes. Putatively assumed species cited in the Electrochemistry Section could not be further characterized and are not numerated.

15 a) M. Cox, R. J. H. Clark and H. J. Milledge, Nature, 1966, 212, 1357; b) R. C. Fay and R. N. Lowry, Inorg. Chem., 1967, 6, 15121519; c) C. A. Wilkie, G.-Y. Lin and D. T. Haworth, J. Inorg. Nucl. Chem., 1978, 40, 1009-1012; d) D. T. Haworth, G. Lin and C. A. Wilkie, J. Fluorine Chem., 1978, 11, 191-196.

16 Reference $15 \mathrm{~b}$ reports the X-ray powder diffraction data

17 J. Köhler, A. Simon, L. van Wüllen, S. Cordier, T. Roisnel, M. Poulain and M. Somer, Z. Anorg. Allg. Chem., 2002, 628, 2683-2690.

18 H.-G. Nieder-Vahrenholz and H. Schäfer, Z. anorg. Allg. Chem., 1987, 544, 122-126.

19 G. Ferguson and C. Glidewell, Acta Crystallogr., Sect. C: Cryst. Struct. Commun., 2001, 57, 264-265.

20 a) E. Dubler, R. Buschmann and H. W. Schmalle, J. Inorg. Biochem., 2003, 95, 97-104; b) L. Matilainen, I. Mutikainen and M. Leskela, Acta Chem. Scand., 1996, 50, 755-758; c) C. Glidewell, G. M. Turner and G. Ferguson, Acta Crystallogr., Sect. C: Cryst. Struct. Commun., 1996, 52, 11-14

21 Y.-R. Luo and J. A. Kerr, Bond Dissociation Energies, in CRC Handbook of Chemistry and Physics, 2007, (87 ${ }^{\text {th }}$ Edition $)$, D. R. Lide, Ed., Taylor and Francis, Boca Raton, FL.

22 a) R. Bini, C. Chiappe, F. Marchetti, G. Pampaloni and S. Zacchini, Inorg. Chem., 2010, 49, 339-351. b) F. Marchetti, G. Pampaloni and S. Zacchini, J. Fluorine Chem., 2010, 131, 21-28.

23 a) S. L. Benjamin, W. Levason and G. Reid, Chem. Soc. Rev., 2013 42, 1460-1499. b) S. L. Benjamin, A. Hyslop, W. Levason and G. Reid, J. Fluorine Chem., 2012, 137, 77-84.

24 K.C. Moss, J. Chem. Soc., 1970, 1224-1226.

25 S. Meyer, Electrochim. Acta, 2004, 49, 3319-3325.

26 M. Cox, J. Lewis and R. S. Nyholm, J. Chem. Soc., 1965, 2840-2844.

27 a) R. B. vonDreele and R. C. Fay, J. Am. Chem. Soc., 1972, 94, 79357936: b) T. W. Hambley, C. J. Hawkins and T. A. Kabanos, Inorg. Chem., 1987, 26, 3740-3745.

28 The crystals of $\left[\mathrm{V}(\mathrm{acac})_{3}\right]\left[\mathrm{TaF}_{6}\right], \mathbf{4 b}$, showed severe twinning which prevented full solution and refinement. Nonetheless, after analysing different crystals and partially solving them in different space groups, it is reasonable to conclude that they contain the $\left[\mathrm{V}(\mathrm{acac})_{3}\right]^{+}$cation and the $\left[\mathrm{TaF}_{6}\right]^{-}$anion. Best information has been obtained by solving the structure in the space group $C 2 \mathrm{a}=10.669(9) \AA, \mathrm{b}=18.361(9) \AA$, $\mathrm{c}=10.509(9) \AA, \beta=90.065(10)^{\circ}$ with both pseudo-merohedral and racemic twinning. Alternatively, the same structure has been solved in the space group $P-31 c \mathrm{a}=\mathrm{b}=10.618(4) \AA, \mathrm{c}=10.509(6) \AA$ with non-merohedral twinning.

29 C. Djordjević and V. Katović, J. Inorg. Nucl. Chem., 1963, 25, 10991109 .

30 Cambridge Crystallographic Data Centre, ConQuest, Version 1.15, 2013

31 C. A. Wilkie, G. Lin and D. T. Haworth, Inorg. Synth., 1979, 19, $145-148$.

32 a) K. Vorres and J. Donohue, Acta Crystallogr., 1955, 8, 25-26; b) J. H. Moss and A. Wright, J. Fluorine Chem., 1975, 5, 163-167.

33 P. Ehrlich and W. Engel, Z. anorg. Allg. Chem., 1962, 317, 21-24. 
34 M. Pasquali, F. Marchetti and C. Floriani, Inorg. Chem., 1979, 18 2401-2404.

35 V. Guiot, I. Suarez-Martinez, P. Wagner, J. Goss, P. Briddon, A. W Allaf and C. P. Ewels, Inorg. Chem., 2009, 48, 3660-3666.

36 a) R.C. Sausa and A. M. Ronn, J. Chem. Phys., 1984, 81, 1716-1724; b) A. Yajima, R. Matsuzaki and Y. Saeki, Bull. Chem. Soc. Jpn., 1978, 51, 1098-1100.

37 G. Pampaloni and P. Zanello, Redox Chemistry and Electrochemistry of Metal Enolates, in The Chemistry of Metal Enolates, 2009, J Zabicky Ed., Part 1, Wiley, Chichester, UK, 461-550.

38 NMR experiments pointed out that $\mathrm{M}^{\prime} \mathrm{O}(\mathrm{acac})_{2}\left(0.250 \mathrm{mmol} ; \mathrm{M}^{\prime}=\mathrm{Ti}\right.$, $\mathrm{V})$ did not react with $\left[\mathrm{NEt}_{4}\right]\left[\mathrm{PF}_{6}\right](0.250 \mathrm{mmol})$ in $\mathrm{CDCl}_{3}$ solution $(0.70 \mathrm{~mL})$

39 M. Asri Nawi and T. L. Riechel, Inorg. Chem., 1981, 20, 1974-1978.

40 P. Zanello, Inorganic Electrochemistry, RSC, Cambridge, 2003.

41 a) R. Taube, S. Wache and J. Sieler, J. Organomet. Chem., 1993 , 459, 335-347; b) M.-C. Chen, J. A. S: Roberts and T. J. Marks Organometallics, 2004, 23, 932-935.

42 Yu. V. Kokunov, M. M. Ershova and G. A. Razgonyaeva, Russ. J. Coord. Chem., 2002, 28, 461-463.

43 A. A. Shinkle, A. E. S. Sleightholme, L. T. Thompson and C. W. Monroe, J. Appl. Electrochem., 2011, 41, 1191-1199.

44 Reduction of $\left[\mathrm{TaF}_{6}\right]^{-}$at $-2.17 \mathrm{~V}$ vs $\operatorname{SCE}\left(-2.55 \mathrm{~V}\right.$ vs. $\left.\mathrm{FeCp}_{2}\right)$ in $\mathrm{CH}_{3} \mathrm{CN} /\left[\mathrm{NEt}_{4}\right]\left[\mathrm{PF}_{6}\right]$ was reported: S. A. Macgregor and K H. Moock, Inorg. Chem, 1998, 37, 3284-3292.

45 W. J. Middleton, Org. Synth., 1990, 7, 528
D. A. Skoog, D. M. West and F. J. Holler, Fundamentals of Analytical Chemistry, 7th Edition, Thomson Learning, Inc, USA, 1996.

50 The unit cell data resembled those available for this previously crystallographically-characterized compound, see reference 51.

51 N. Serpone, P. H. Bird, A. Somogyvari and D. G. Bickley, Inorg. Chem., 1977, 16, 2381-2386

52 IR spectrum of $\mathrm{TiOCl}_{2}$ : L. A. Bruno and B. C. Beard, Appl. Spectr., 1997, 51, 131-133

53 IR spectrum of TiOF 2 : K. Dehnicke, Naturwissenschaften, 1965, 52, 660 .

54 The unit cell data collected for $\mathbf{1 b}$ resembled those available for this previously crystallographically-characterized compound (see reference 19)

55 IR spectrum of $\mathrm{VOCl}_{2}, \mathbf{8 b}$, in Nujol mull: Spectral Database for Organic Compounds (SDBS), http://riodb01.ibase.aist.go.jp/sdbs/cgibin/direct_frame_top.cgi.

56 G. M. Sheldrick, SADABS, University of Göttingen, Göttingen, Germany.

57 G. M. Sheldrick, SHELX97, University of Göttingen, Göttingen, Germany. 